\title{
Experimental study of a rehabilitation solution that uses GFRP bars to replace the steel bars of reinforced concrete beams
}

\author{
Patrícia Escórcio ${ }^{\mathrm{a}, *}$, Paulo M. França ${ }^{\mathrm{b}}$ \\ ${ }^{a}$ CCCEE, Madeira University, Campus Universitário da Penteada, 9020-105 Funchal, Portugal \\ ${ }^{\mathrm{b}}$ CEris, ICIST and CCCEE, Madeira University, Campus Universitário da Penteada, 9020-105 Funchal, Portugal
}

\section{A R T I C L E I N F O}

\section{Article history:}

Received 8 September 2015

Revised 21 June 2016

Accepted 12 September 2016

Available online 28 September 2016

\section{Keywords:}

GFRP bars

Full-scale test

Rehabilitation solution

FRP guidelines

Ultimate limit state

Serviceability limit state

\begin{abstract}
A B S T R A C T
The corrosion of the steel reinforcement affects drastically the long-term durability of many reinforced concrete (RC) structures in the world, especially the ones near the sea. When this problem is detected at early stages, it is possible and important to repair the structure in order to restore its safety and avoid future hazards and more expensive interventions. The research work described in this paper is inspired on these cases as it proposes a rehabilitation solution to replace the tension steel reinforcement of a RC beam with GFRP bars, which is a material immune to corrosion.

The experimental study consisted on six full-scale RC beams subjected to a three-point bending test until failure. The specimens had stirrups without the bottom branch and were casted in two phases to simulate the replacement of the corroded and cracked bottom concrete. Two different GFRP reinforcement ratios were tested to assess the behaviour of the repaired beam regarding its service and ultimate states in comparison with the original beam with steel reinforcement. The results are presented and discussed in terms of flexural capacity, failure modes, deflection, crack pattern, mid-span crack width and reinforcement strains. It was concluded that the presented rehabilitation solution is easy to implement, can be designed according to general FRP design guidelines, and is able to restore the serviceability and ultimate limit states of the original RC beam.
\end{abstract}

(c) 2016 Elsevier Ltd. All rights reserved.

\section{Introduction}

Structural rehabilitation is becoming increasingly important nowadays. The amount of deteriorated structures, the frequency and the costs of rehabilitation interventions motivate the introduction of innovative materials and methods to rehabilitate structures. The service behaviour and the ultimate performance of reinforced concrete (RC) are shortened by the corrosion of steel reinforcement $[1,2]$. Corrosion of the reinforcement induced by chloride environments has a significant effect on the mechanical behaviour, and the loss of cross-sectional area and bond strength of reinforcement have a very important effect on the bending capacity [3]. Malumbela et al. [1] concluded that for a maximum mass loss of $1 \%$, the flexural capacity was reduced by $0.7 \%$. Currently, repairing, rehabilitating and strengthening solutions are being developed and tested using different materials and different layouts. Solutions with steel materials can have limited duration. As alternative, Fibre Reinforced Polymers (FRPs) have been used because of their

\footnotetext{
* Corresponding author.

E-mail addresses: pescorcio@uma.pt (P. Escórcio), pfranca@uma.pt (P.M. França).
}

resistance to corrosion, high strength and light weight. The most common is the use of FRP solutions with sheets or laminates which are externally bonded to replace the structural integrity, in cases of theoretical reinforcement mass loss from 5\% to 15\%. Many experimental studies [4-7] indicate that by optimizing the amount and the layout, the bonded FRP sheets are suitable for balancing the strength recovery and that it is possible to restore the yield and the ultimate capacity with the same or lower deflection than initially. To prevent delamination and debonding problems, Spadea, Bencardino [8] suggested that the strengthening for flexure should be accompanied by the strengthening for shear. Thus, the best layout of bonded FRP sheets as reinforcement is a combination of a bonded sheet on the tension side anchored by U-shaped sheets. Several techniques are being developed to prestress FRP plates prior to bonding, which has already been proven to be an efficient solution [9]. However these solutions may not be effective when applied to damaged beams with more than $50 \%$ mass loss of tensile steel and it is emphasized that additional research is needed for cases where corrosion is severe and part of the reinforcement is missing. Moreover, the epoxy-bonded FRPs have limitations when applied at high temperatures, because of the rapid deterioration of the properties of the polymer matrix [10]. The use of cement base 


\begin{tabular}{|c|c|c|c|}
\hline \multicolumn{4}{|c|}{ Nomenclature } \\
\hline$b$ & width of the rectangular cross-section [m] & $I_{e}$ & Branson's effective moment of inertia $\left[\mathrm{m}^{4}\right]$ \\
\hline d & $\begin{array}{l}\text { distance from the extreme compression fibre to the cen- } \\
\text { troid of the tension reinforcement [m] }\end{array}$ & $\begin{array}{l}I_{g} \\
M_{a}\end{array}$ & $\begin{array}{l}\text { cross-section gross moment of inertia }\left[\mathrm{m}^{4}\right] \\
\text { the moment for the considered load }[\mathrm{kNm}]\end{array}$ \\
\hline$f_{b d}$ & bond strength [Mpa] & $M_{c r}$ & cracking moment $[\mathrm{Nm}]$ \\
\hline$f_{c}^{\prime}$ & compressive strength of concrete [MPa] & $M_{f}$ & function of the bending moment $[\mathrm{kNm}]$ \\
\hline$f_{c d}$ & concrete compressive strength design value [MPa] & $M_{n}$ & moment capacity (nominal moment) $[\mathrm{kNm}]$ \\
\hline$f_{c m}$ & concrete compressive strength [MPa] & $M_{u}$ & ultimate moment resistance $[\mathrm{kNm}]$ \\
\hline$f_{c t m}$ & the mean tensile strength [MPa] & $\beta_{1}$ & factor that takes the value 0.85 when the concrete \\
\hline$f_{f}$ & tensile strength of GFRP bars [MPa] & & strength, $f_{c}^{\prime}$, is lower or equal to $28 \mathrm{MPa}$ and its value \\
\hline$f_{f k}$ & $\begin{array}{l}\text { tensile strength characteristic value of the FRP } \\
\text { reinforcement [MPa] }\end{array}$ & & $\begin{array}{l}\text { decreases continuously at a rate of } 0.05 \text { per each } \\
7 \mathrm{MPa} \text { above the } 28 \mathrm{MPa}[-]\end{array}$ \\
\hline$f_{f u}$ & $\begin{array}{l}\text { the ultimate FRP tensile strength [MPa] } \\
\text { guaranteed tensile strength of an FRP bar [MPa] }\end{array}$ & $\beta_{d}$ & $\begin{array}{l}\text { reduction coefficient used on the deflection } \\
\text { calculation [-] }\end{array}$ \\
\hline$f_{t}^{J u}$ & the maximum tensile [MPa] & $\delta$ & service deflection [m] \\
\hline$f_{y}$ & yield stress [MPa] & $\varepsilon$ & mean strain $[\mathrm{MPa}]$ \\
\hline$h$ & cross-section depth [m] & $\varepsilon_{c u}$ & concrete ultimate strain [MPa] \\
\hline lb & anchorage length $[\mathrm{m}]$ & $\varepsilon_{f}$ & FRP reinforcement tensile strain [MPa] \\
\hline$A_{f}$ & reinforcement area $\left[\mathrm{m}^{2}\right]$ & $\rho_{\mathrm{fb}}$ & balanced reinforcement area $[-]$ \\
\hline$C_{E}$ & environmental factor [-] & $\rho_{\mathrm{f}}$ & reinforcement area $[-]$ \\
\hline $\mathrm{E}$ & elasticity modulus [GPa] & $\rho_{\mathrm{s}}$ & reinforcement area of steel [-] \\
\hline
\end{tabular}

adhesives can be a solution for the application on structures located in hot regions or when there is a high danger of fire [11].

Rehabilitation solutions using FRP bars are not so frequent. One of the reasons may be that the FRP bar design as reinforcement is still uncommon, although this material has been available on the market for over 15 years. Several factors, such as novelty, production costs, the low modulus of elasticity, the non-ductile behaviour, the different design philosophies, and the need to validate the behaviour, have been responsible for the low levels of its application. Several authors $[2,12]$ suggest that the analytical procedures developed for the design of reinforced concrete with steel bars in terms of ultimate loads, deflection and crack width are not applicable to the design of reinforced concrete with FRP bars (FRP RC) due to the mechanical property differences. Additionally, the design of FRP RC is generally governed by serviceability. However, the majority of codes and guidelines developed until now [12,13], use the same equations developed for steel reinforced members, modified to account for the differences between the materials $[12,13]$. Several authors [12-15] have been studying the ultimate and service behaviour of FRP RC. Since the behaviour FRP RC beams is bilinear until failure, reducing stiffness after cracking, most of the guides and codes recommend the flexural design according to a compression failure due to its less catastrophic mode [2]. This forces the design of over-reinforced cross-sections, providing a reduction in service load deflections and crack width and lower FRP bars stress. It is suggested that compression failures present better member deformability and gradual member failure than FRP rupture [15]. In serviceability, due to the lower modulus of elasticity of FRPs and to the different bonding properties, larger deflections and crack widths are expected than in steel RC beams. Several models and approaches for predicting deflections and crack width have been proposed, but some controversy remains. Several authors [16] reported that the deflections of FRP RC can be predicted with the original ACI 318 [17] formulas developed for steel reinforced concrete. On the other hand, other experimental analyses [18-20] pointed out that the modifications proposed in ACI 440.1R-06 [12] relative to ACI 318 are needed, achieving accurate predictions with this approach. Other studies [21] propose different methods. The Yost et al. [22] and Toutanji and Saafi's [14] findings suggest that the effective moment of inertia, used in the ACI
318 formula to predict the deflection, is overestimated and that it is possible to establish a correlation between the degree of overestimation and the ratio between the reinforcement area and the balanced reinforcement area $\left(\rho_{\mathrm{f}} / \rho_{\mathrm{fb}}\right)$ : the higher the ratio $\rho_{\mathrm{f}} / \rho_{\mathrm{fb}}$, the lower the error of the effective moment of inertia value. They also proposed alternative equations for the effective moment of inertia and for deflection.

The serviceability verification depends on bond and elasticity modulus, a certain equation can predict the behaviour well for one type of FRP bars but not for another of a different material or with a different surface $[2,13,14]$. Among the different fibres used to make FRPs, glass fibres are the most common as they are the least expensive.

Furthermore, other studies [2] indicate the use of high strength concrete (HSC) to make better use of FRPs' properties.

Some experimental works of the near surface mounted (NSM) reinforcement technique were done to rehabilitate concrete structures damaged by corrosion [23]. This technique consists in bonding FRP rods with epoxy resins in undamaged areas of concrete cover. Results indicate that it is possible for repaired beams to achieve the same ultimate capacity as the control beam but differing in the failure modes [24] and showing a ductility reduction in comparison with traditional RC beams. However, a significant disadvantage of this technique is that the placing of the NSM rods is highly dependent on the quality of the concrete cover, which is frequently damaged by steel corrosion. If this is the case, this solution cannot be applied.

The issues listed in the preceding paragraphs justify the research described in this paper. Additionally, rehabilitation or repairing solutions using FRP sheets or textiles, or even the application of FRP bars with NSM, cannot be applied in many cases, such as when the reinforcement mass loss due to corrosion is high, when the concrete cover is extremely damaged or when it is not possible to increase the depth of the section. As a consequence of these facts, the rehabilitation solution adopted in these cases tends to be the replacement of the corroded steel by new steel reinforcement. However, when the deterioration of the RC structure is due to steel corrosion, the replacement of this material by another that is immune to this problem, such as GFRP, is an additional guaranty for a long-term duration of the rehabilitation solution. 
The main objective of the present research is to simulate and assess the behaviour of a rehabilitation intervention using GFRP bars on RC beams, in cases of bottom steel reinforcement highly damaged by corrosion and which forces its total removal. An experimental campaign on six full-scale beams was carried out, with the removal of the corroded steel reinforcement being simulated, and a rehabilitation method was developed and applied using GFRP bars. The rehabilitated beams were subjected to three-point bending tests until failure and the load-deflection response was analysed and compared with a reference beam and with theoretical predictions.

\section{Experimental programme}

A total of six full-scale RC beams (one reference and five rehabilitated beams) were cast and tested under three-point bending until failure. The beams were designated according to their characteristics as reference and rehabilitated with steel or GFRP reinforcement. The rehabilitated specimens were concreted in two phases at different dates to simulate the different material layers composed by the original and the rehabilitation concretes with different ages. Several other procedures were also performed to simulate the real conditions when the corroded tension reinforcement has to be removed, such as: use of closed stirrups without the bottom branch to simulate its total destruction due to corrosion; picking the tension surface of the beam to enhance the bonding between the different concrete layers (Fig. 1(a)); drilling the intersections with other structural elements (for example columns) to insert a new reinforcement; and filling the holes with resin in the anchorage zone at the end of the longitudinal reinforcement (Fig. 1(b) and (c)).

\subsection{Material properties}

\subsubsection{Concrete}

The concrete strength for all test specimens was a selfcompacting (SCC) C30/37 and its composition is presented in Table 1.
Table 2 shows the concrete properties. The strength at 28 days of concrete was determined by compression tests of three cubic samples with $0.15 \mathrm{~m}$ edge and three cylinders with $0.15 \mathrm{~m}$ in diameter and $0.30 \mathrm{~m}$ high. For additional information about the compression strength, a compression test was made on each beam testing day. The elasticity modulus, E, was also experimentally determined since it is particularly important in SCC because it varies with the lithological type of its aggregates. Although its value tends to increase with increasing compression strength, this increase appears to be lower when fly ash and limestone elements are introduced [26]. At 28 days the expected value for the elasticity modulus of C30/37 was at least $33 \mathrm{GPa}$ [27] but tested samples had a lower value.

\subsubsection{Steel reinforcement bars}

The steel grade of reinforcement used in the reference beams and in compression reinforcement of all beams was A500. In order to determine the mean values of yield stress $\left(f_{y}\right)$, the maximum tensile $\left(f_{t}\right)$ and the elasticity modulus $(E)$, three samples of each diameter used were tested in pure tension, according to standard NP EN ISO 6892-1:2012 [28]. Reinforcement bars of $12 \mathrm{~mm}$ and $16 \mathrm{~mm}$ were used as longitudinal reinforcement and bars of $8 \mathrm{~mm}$ in diameter were used as shear reinforcement in the form of stirrups. The results of pure tension tests are presented in Table 3.

\subsubsection{GFRP bars}

The type and shape of the GFRP bars used in this experimental study are shown in Fig. 2. This reinforcement is a straight bar with a helically grooved surface to increase the bonding to the concrete and headed ends to enhance the anchorage capacity. To compare with the property values presented by the producer, three straight bar samples of each diameter, $12 \mathrm{~mm}$ and $25 \mathrm{~mm}$, were tested in pure tension to determine the stress-strain relationship and the tensile strength $\left(\mathrm{f}_{\mathrm{f}}\right)$.

The properties of the GFRP bars according to the producer are presented in Table 4.
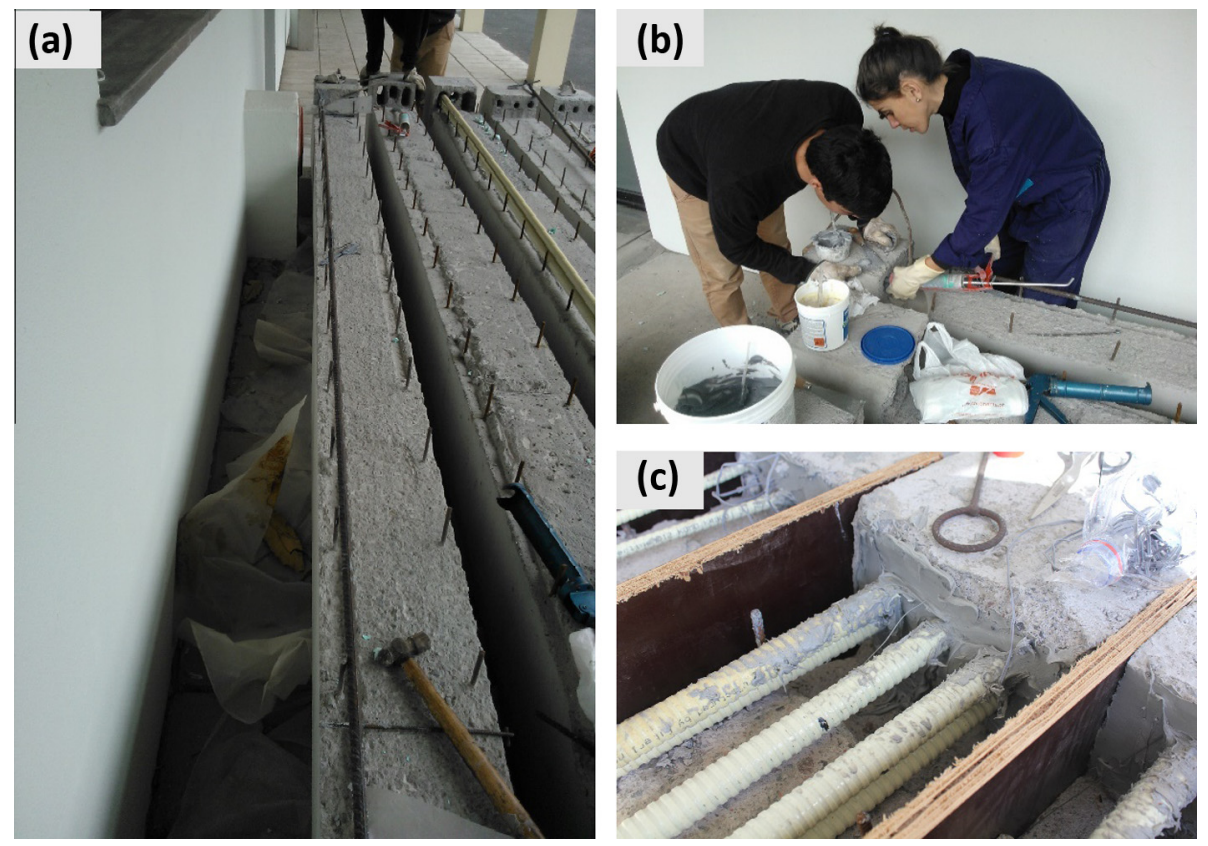

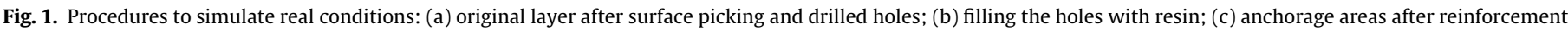
insertion and the filling of the holes. 
Table 1

Concrete composition according to BETOMADEIRA information.

\begin{tabular}{|c|c|c|c|c|c|c|c|c|c|c|c|c|}
\hline SCC - EN & $206-9[2$ & C30/37 & $\mathrm{KC} 4(\mathrm{P}) \mathrm{Cl}$ & $0.2 \mathrm{D}$ & 6 SF2 SR2 & & & & & & & \\
\hline Material & Water & Cement & Clinker & $\begin{array}{l}\text { Fly } \\
\text { Ash }\end{array}$ & $\begin{array}{l}\text { Limestone } \\
\text { filler }\end{array}$ & $\begin{array}{l}\text { Additional minority } \\
\text { constituents (EN-197) }\end{array}$ & $\begin{array}{l}\text { Gravel } \\
8 / 16\end{array}$ & $\begin{array}{l}\text { Gravel } \\
4 / 10\end{array}$ & $\begin{array}{l}\text { Stone dust - } \\
\mathrm{AB} 0 / 4\end{array}$ & $\begin{array}{l}\text { Sand } \\
0 / 2\end{array}$ & $\begin{array}{l}\text { G SKy } 548 \\
\text { (adjuvant) }\end{array}$ & $\begin{array}{l}\text { Pozolith 390N } \\
\text { (adjuvant) }\end{array}$ \\
\hline $\mathrm{kg} / \mathrm{m}^{3}$ & 185 & 350 & 280 & 100 & 47.5 & 22.5 & 200 & 575 & 661 & 402 & 5.8 & 3.5 \\
\hline
\end{tabular}

Table 2

Concrete properties.

\begin{tabular}{|c|c|c|c|c|c|c|c|c|c|c|}
\hline \multirow{3}{*}{$\begin{array}{l}\text { Beam } \\
\text { designation }\end{array}$} & \multicolumn{10}{|l|}{ Concrete } \\
\hline & \multicolumn{2}{|c|}{ Concrete age [Days] } & \multicolumn{2}{|c|}{$\begin{array}{l}\text { Cylinder/cube strength, } \\
\mathrm{f}_{\mathrm{cm}, 28}[\mathrm{MPa}]\end{array}$} & \multicolumn{2}{|c|}{$\begin{array}{l}\text { Cylinder strength, } \mathrm{f}_{\mathrm{cm}} \\
{[\mathrm{MPa}]}\end{array}$} & \multicolumn{2}{|c|}{$\begin{array}{l}\text { Elasticity modulus, } \mathrm{E}_{\mathrm{cm} 28} \\
{[\mathrm{GPa}]}\end{array}$} & \multicolumn{2}{|c|}{$\begin{array}{l}\text { Elasticity modulus, } \mathrm{E}_{\mathrm{cm}} \\
{[\mathrm{GPa}]}\end{array}$} \\
\hline & $\begin{array}{l}\text { Original } \\
\text { layer }\end{array}$ & $\begin{array}{l}\text { Rehab } \\
\text { layer }\end{array}$ & $\begin{array}{l}\text { Original } \\
\text { layer }\end{array}$ & $\begin{array}{l}\text { Rehab } \\
\text { layer }\end{array}$ & $\begin{array}{l}\text { Original } \\
\text { layer }\end{array}$ & $\begin{array}{l}\text { Rehab } \\
\text { layer }\end{array}$ & $\begin{array}{l}\text { Original } \\
\text { layer }\end{array}$ & $\begin{array}{l}\text { Rehab } \\
\text { layer }\end{array}$ & $\begin{array}{l}\text { Original } \\
\text { layer }\end{array}$ & $\begin{array}{l}\text { Rehab } \\
\text { layer }\end{array}$ \\
\hline REF & 253 & & $40.4 / 46.9$ & & 47.7 & & 27 & & 29 & \\
\hline REHABSTEEL & 281 & 48 & $40.4 / 46.9$ & $39.9 / 41.5$ & 47.9 & 39.9 & 27 & 23 & 29 & 26 \\
\hline REHABGFRP1A & 295 & 62 & & & 48.0 & 39.9 & & & & \\
\hline REHABGFRP1B & 323 & 90 & & & 48.2 & 39.9 & & & & \\
\hline REHABGFRP2A & 282 & 49 & & & 47.9 & 39.9 & & & & \\
\hline REHABGFRP2B & 287 & 54 & & & 48.0 & 39.9 & & & & \\
\hline
\end{tabular}

Table 3

Yield stress, tensile strength and elasticity modulus of the steel reinforcement bars.

\begin{tabular}{|c|c|c|c|c|c|c|}
\hline \multirow[t]{2}{*}{$\Phi[\mathrm{mm}]$} & \multicolumn{2}{|c|}{$\begin{array}{l}\text { Yield stress, } \mathrm{f}_{\mathrm{y}} \\
{[\mathrm{MPa}]}\end{array}$} & \multicolumn{2}{|c|}{$\begin{array}{l}\text { Tensile strength, } \mathrm{f}_{\mathrm{t}} \\
\text { [MPa] }\end{array}$} & \multicolumn{2}{|c|}{$\begin{array}{l}\text { Elasticity modulus, E } \\
\text { [GPa] }\end{array}$} \\
\hline & Sample & Mean & Sample & Mean & Sample & Mean \\
\hline 8 & $\begin{array}{l}763.0 \\
603.7 \\
644.8\end{array}$ & 670 & $\begin{array}{l}834.4 \\
674.5 \\
717.2\end{array}$ & 743 & $\begin{array}{l}251.2 \\
210.4 \\
227.4\end{array}$ & 230 \\
\hline 12 & $\begin{array}{l}628.3 \\
540.7 \\
648.7\end{array}$ & 605 & $\begin{array}{l}749.0 \\
660.7 \\
762.9\end{array}$ & 721 & $\begin{array}{l}202.7 \\
208.8 \\
214.0\end{array}$ & 209 \\
\hline 16 & $\begin{array}{l}718.2 \\
648.8 \\
680.4\end{array}$ & 682 & $\begin{array}{l}844.6 \\
810.8 \\
805.8\end{array}$ & 820 & $\begin{array}{l}206.3 \\
206.0 \\
241.9\end{array}$ & 218 \\
\hline
\end{tabular}

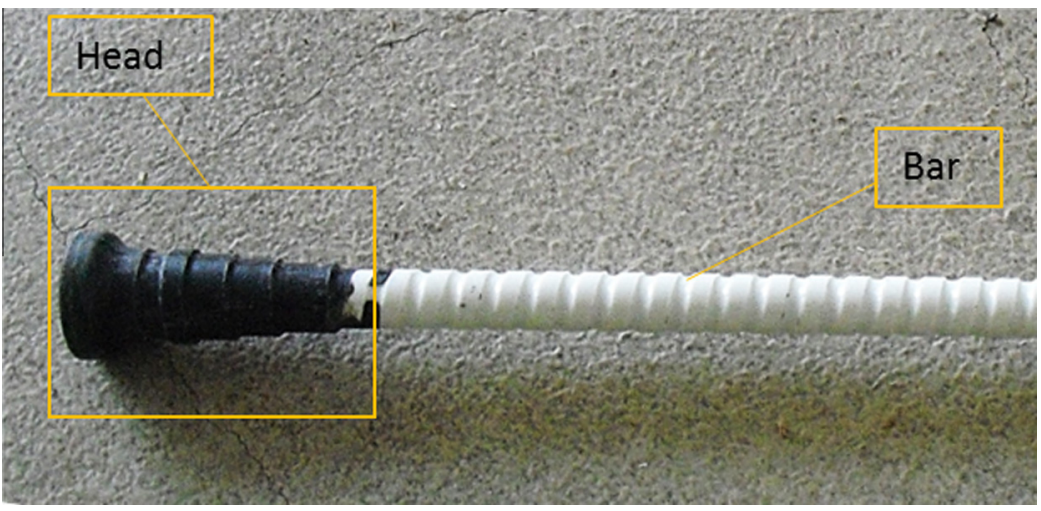

Fig. 2. Sample of GFRP bar with polymeric conic head at the end.

The conic end heads are made of polymeric concrete [30] and they are cast at the ends of the straight bars. Their geometry insures minimal tensile splitting forces at the heads, which allows the position of the bar very close to the concrete surface and where it is still possible to develop its full design force. In addition, these heads reduce the required bonding length, $\mathrm{lb}$, of the straight bars [30].

The results of the pure tension tests are presented in Table 5. These values were in agreement with the values indicated by the producer for the $12 \mathrm{~mm}$ bars. For the $25 \mathrm{~mm}$ bars, the tensile strength values were lower than expected due to the premature failure at the clamped ends.

\subsubsection{Filling resin for the anchorage of the reinforcement in the} rehabilitation beams

The material used for the anchorage of the reinforcement in the rehabilitation solution was a two-component epoxy resin without shrinkage and with a bond strength to concrete higher than $3 \mathrm{MPa}$ [32]. 
Table 4

GFRP bars properties according to the producer [29].

\begin{tabular}{|c|c|c|c|c|c|c|c|}
\hline ComBAR & $\begin{array}{l}\text { Exterior diameter } \\
{[\mathrm{mm}]}\end{array}$ & $\begin{array}{l}\text { Interior diameter } \\
{[\mathrm{mm}]}\end{array}$ & $\begin{array}{l}\text { Cross-sectional area } \\
{\left[\mathrm{mm}^{2}\right]}\end{array}$ & $\begin{array}{l}\text { Specific mass } \\
{[\mathrm{kg} / \mathrm{m}]}\end{array}$ & $\begin{array}{l}\text { Tensile strength, } \mathrm{f}_{\mathrm{f}} \\
\text { [MPa] }\end{array}$ & $\begin{array}{l}\text { Elasticity modulus, } \mathrm{E}_{\mathrm{f}} \\
\text { [GPa] }\end{array}$ & $\begin{array}{l}\text { Bond strength, } \mathrm{f}_{\mathrm{bd}} \\
{[\mathrm{MPa}]}\end{array}$ \\
\hline 12 & 13.5 & 12 & 113 & 0.30 & 1350 & \multirow[t]{2}{*}{60} & \multirow{2}{*}{$\begin{array}{l}3.0 \\
(\text { For C30/37) }\end{array}$} \\
\hline 25 & 27 & 25 & 491 & 1.22 & 1100 & & \\
\hline
\end{tabular}

Table 5

Mechanical properties obtained at pure tension test [31].

\begin{tabular}{|c|c|c|c|c|c|c|}
\hline \multirow[t]{2}{*}{ ComBAR [mm] } & \multicolumn{2}{|c|}{$\begin{array}{l}\text { Tensile strength [MPa] } \\
\text { [MPa] }\end{array}$} & \multicolumn{2}{|c|}{$\begin{array}{l}\text { Modulus of elasticity } \\
\text { [GPa] }\end{array}$} & \multicolumn{2}{|c|}{$\begin{array}{l}\text { Ultimate strain } \\
{[\% o]}\end{array}$} \\
\hline & Sample & Mean & Sample & Mean & Sample & Mean \\
\hline 12 & $\begin{array}{l}949.6 \\
1315.3 \\
1336.8\end{array}$ & 1200.0 & $\begin{array}{l}61.8 \\
61.3 \\
61.3\end{array}$ & 60.0 & $\begin{array}{l}15.4 \\
21.5 \\
21.5\end{array}$ & 19.0 \\
\hline 25 & $\begin{array}{l}777.3 \\
610.9 \\
798.5\end{array}$ & 729.0 & $\begin{array}{l}59.3 \\
68.7 \\
65.0\end{array}$ & 64.0 & $\begin{array}{l}13.1 \\
8.9 \\
12.3\end{array}$ & 11.0 \\
\hline
\end{tabular}

\subsection{Test set-up}

\subsubsection{Beam specimens}

A total of six full-scale RC beams were tested under three-point bending until failure. The beam specimens were $4.30 \mathrm{~m}$ long with a free span of $4.00 \mathrm{~m}$ and a rectangular cross-section of $0.25 \times 0.40 \mathrm{~m}^{2}$. In all specimens a compressive longitudinal reinforcement was used of two steel bars $12 \mathrm{~mm}$ in diameter, a shear reinforcement of $8 \mathrm{~mm}$ diameter stirrups with $0.25 \mathrm{~m}$ spacing and a concrete cover of $2.5 \mathrm{~cm}$. Four different types of beams were considered according to their characteristics:

(1) 1 RC beam as reference (REF);

(2) 1 rehabilitated beam with steel reinforcement (REHABSTEEL) to have similar behaviour as the reference beam;

(3) 2 rehabilitated beams with GFRP reinforcement with the same load capacity as the reference beam (REHABGFRP1 A and $\mathrm{B}$ );

(4) 2 rehabilitated beams with GFRP reinforcement with the same mid-span deflection as the reference beam (REHABGFRP2 A and B).

The REF specimen is a non-deteriorated conventional steel RC beam with two bottom longitudinal $16 \mathrm{~mm}$ diameter bars $(2 \phi 16)$ to determine the reference behaviour and values of the load capacity and the mid-span deflection to be reproduced by the other five rehabilitated beams. The REF beam was concreted in a single phase, and its stirrups had the conventional closed shape with four branches. The rehabilitated beams were concreted in two phases and their stirrups had only three branches, reproducing a real situation where the bottom branch had already been corroded. This procedure was adopted to evaluate the influence of different concrete layers and the absence of the stirrup bottom branch on the behaviour of the rehabilitated beams.

The REHABSTEEL specimen is a rehabilitated beam with the same cross-section geometry and steel reinforcement as the REF beam and therefore should exhibit similar behaviour. The objective of this beam was to conclude if the rehabilitation solution with the new concrete layer and the absence of the stirrup bottom branch would affect the performance of the rehabilitated beam.

The REHABGFRP1 - A and B specimens are equal rehabilitated beams with three bottom GFRP longitudinal $12 \mathrm{~mm}$ diameter bars ( $3 \phi 12)$ designed to have the same ultimate load as the REF beam, keeping the cross-section geometry. Due to the lower modulus of elasticity of the GFRP material in comparison with steel, it is not possible to obtain the same deflection in these beams as in the REF beam. In fact, considering that the steel reinforcement area of the REF beam is $18.6 \%$ higher and its modulus of elasticity is 3.6 times higher, a significantly higher deflection is expected in the REHABGFRP1 beams.

The most efficient solution to design a rehabilitated beam with GFRP bars with the same load capacity and deflection as the reference beam is to increase the height of the cross-section. However there are two main problems with this solution. It must be possible from an architectural point of view and most importantly it may have some deficiencies in its shear behaviour due to the fact that the stirrups vertical branches become too short, only overcome by a shear strengthening which would largely complicate the solution. Another possibility within the solution of increasing the height of the beam is to keep the longitudinal bars in the original position at the bottom of the stirrups vertical branches, meaning that the rehabilitated beam would have a higher concrete cover. Nevertheless, none of these possibilities were tested because it was decided in this research work to keep the original geometry of the specimen, which was the easiest and the best solution to avoid compromising the shear behaviour of the rehabilitated beam.

Because of this issue, the REHABGFRP2 - A and B specimens are equal rehabilitated beams with the same cross-section geometry as the REF beam and five bottom GFRP longitudinal $25 \mathrm{~mm}$ diameter bars $(5 \phi 25)$ designed to have the same service mid-span deflection.

A schematic representation of the test set-up and the different cross-sections are shown in Fig. 3. Table 6 presents information about all reinforcement in all beams and a detailed description of the tests instrumentation used is presented in Section 2.2.2. Due to the three-point bending test configuration and the $4.0 \mathrm{~m}$ span, it is possible to conclude that the ratio between the applied load and the bending moment is one.

\subsubsection{Tests instrumentation}

The instrumentation used during the loading tests is indicated in Figs. 3 and 4. At each support there were two load cells (Fig. 5 (a)) (LC1 and LC4; LC2 and LC3), each one with $200 \mathrm{kN}$ load capacity, to monitor the reaction forces. Their sum of values is the applied load. Two linear variable differential transducers (LVDT1 and LVDT2) (Fig. 5(b)) with a maximum capacity of $100 \mathrm{~mm}$ were installed on each beam at the mid-span to measure the deflection. These sensors were placed on both sides and on top of the beams, as shown in Fig. 4, to prevent their being damaged during the tests. 

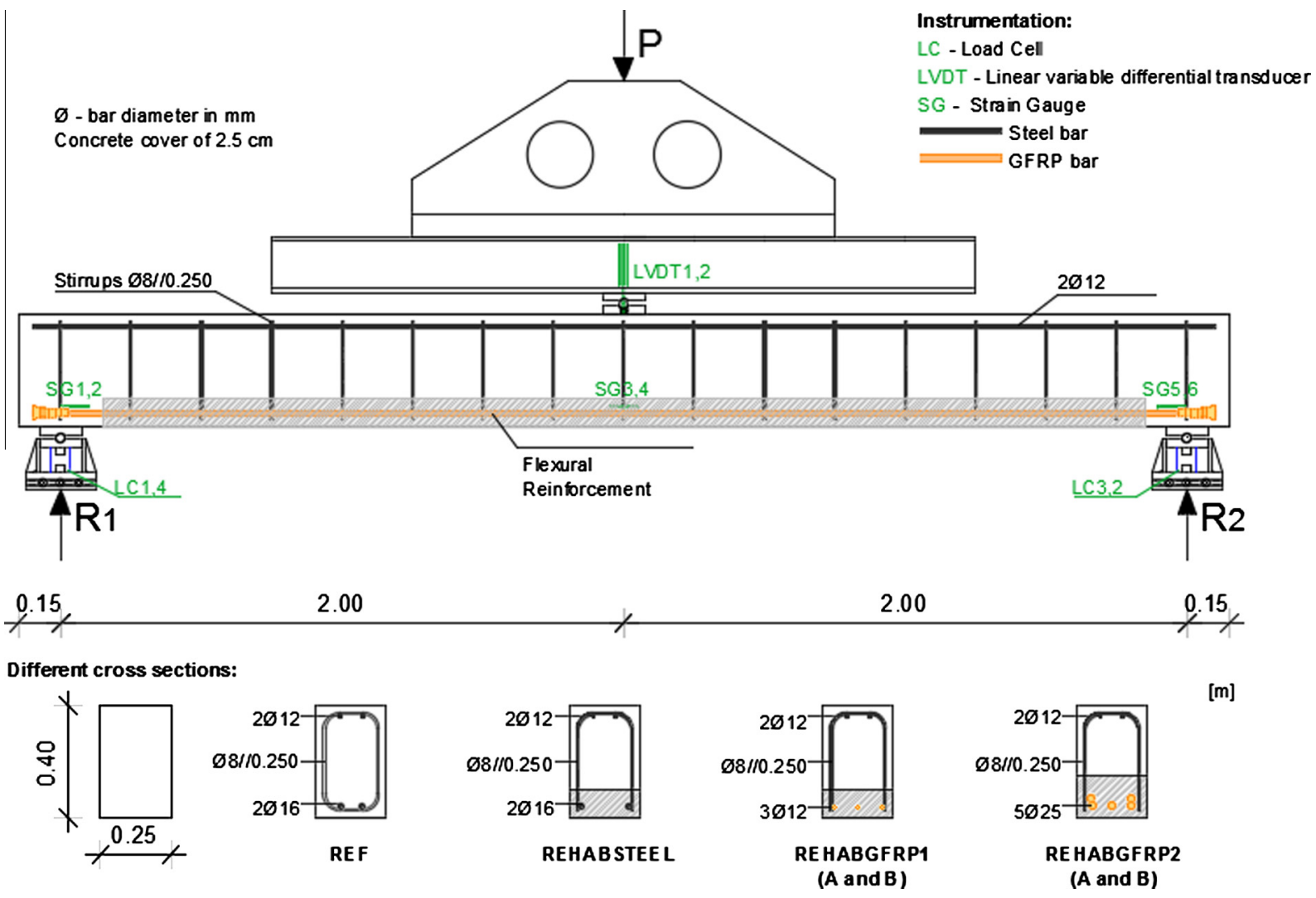

[m]

Fig. 3. Test set-up and specimens configuration.

Table 6

Beams reinforcement

\begin{tabular}{|c|c|c|c|c|c|c|c|c|c|}
\hline \multirow[t]{2}{*}{ Beam designation } & \multicolumn{3}{|c|}{ Tension reinforcement } & \multicolumn{3}{|c|}{ Compression reinforcement } & \multicolumn{3}{|c|}{ Transversal reinforcement } \\
\hline & Type & Bars & $\begin{array}{l}\rho \\
(\%)\end{array}$ & Type & Bars & $\begin{array}{l}\rho \\
(\%)\end{array}$ & Type & Bars & $\begin{array}{l}\rho \\
(\%)\end{array}$ \\
\hline REF & Steel & $2 \phi^{\mathrm{a}} 16$ & 0.40 & Steel & $2 \phi 12$ & 0.226 & Steel & $\phi 8 / / 0.250^{\mathrm{b}}$ & 0.40 \\
\hline REHABSTEEl & & $4.02 \mathrm{~cm}^{\mathrm{b}}$ & & & $2.26 \mathrm{~cm}^{\mathrm{b}}$ & & & & \\
\hline REHABGFRP1 A & GFRP & $3 \phi 12$ & 0.34 & & & & & & \\
\hline REHABGFRP1 B & & $3.39 \mathrm{~cm}^{\mathrm{b}}$ & & & & & & & \\
\hline REHABGFRP2 A & & $5 \phi 25$ & 2.50 & & & & & & \\
\hline REHABGFRP2 B & & $24.54 \mathrm{~cm}^{\mathrm{b}}$ & & & & & & & \\
\hline
\end{tabular}

a $\phi$ is the bar diameter in millimetres.

b $\phi 8 / / 0.250$ means two branches of $8 \mathrm{~mm}$ stirrups spaced at $25 \mathrm{~cm}$.

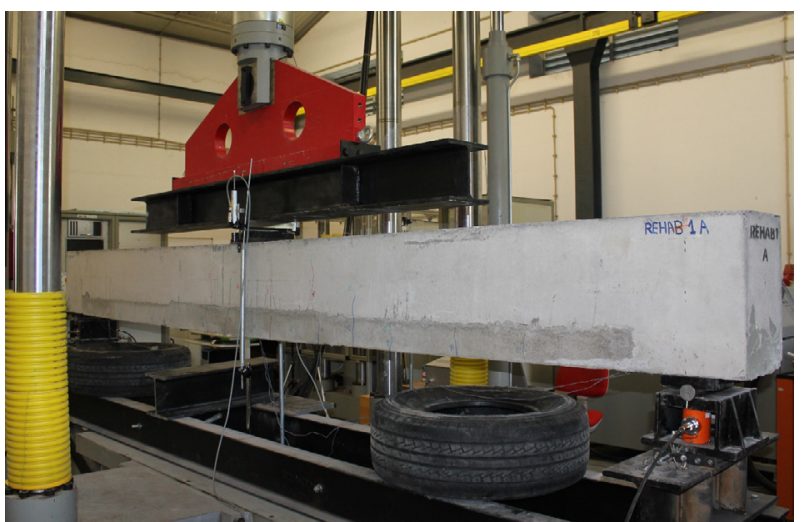

Fig. 4. Beam test set-up.
The tension reinforcement bars were instrumented with six glued strain gauges (SG1 to SG6) to monitor the strains at midspan and at each support (two at each location) According to the manufacturer, the used strain gauges are indicated for general use and are made of a single element, a foil of the elements copper and nickel with a length of $5 \mathrm{~mm}$. The maximum strain capacity is of the order of $21 \pm 1 \%$, the gauge factor $(G F)$ is $2.13 \pm 1 \%$ and the resistance is $120 \pm 0.3 \Omega$ [33].

2.2.3. The production of the beam specimens and the rehabilitation procedure

To simulate the real situation where the corroded steel tension reinforcement has to be removed, the beam specimens were concreted in two phases. The main steps of the production of the beam specimens and their rehabilitation procedure are presented and summarized in Fig. 6. 


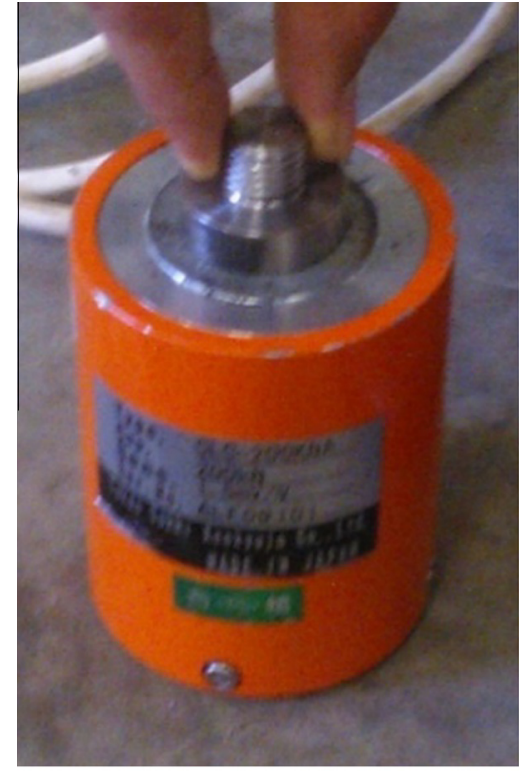

(a)

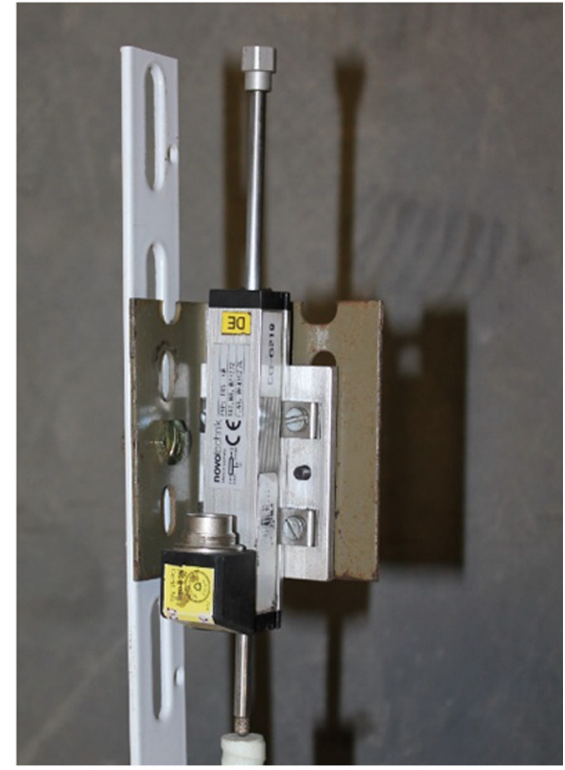

(b)

Fig. 5. Instrumentation used in the tests: (a) Load-cell; (b) LVDT.

1) Concreting of the beam upside down

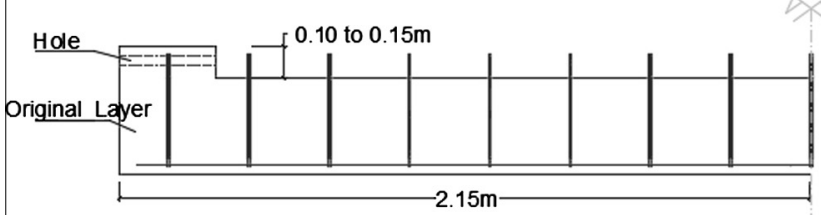

2) Insertion of the tension reinforcement and the resin at the anchorage ends

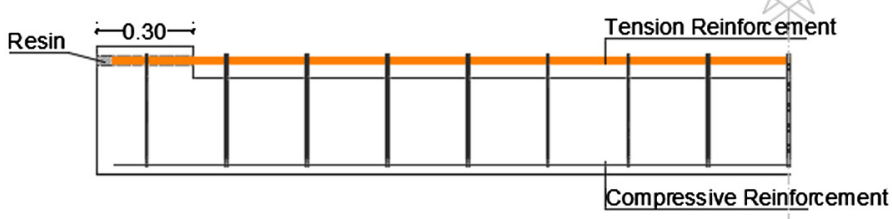

3) Concreting of the rehabilitation concrete layer

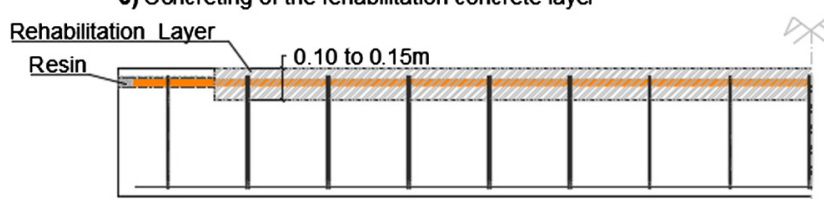

4) Rotation of the beam

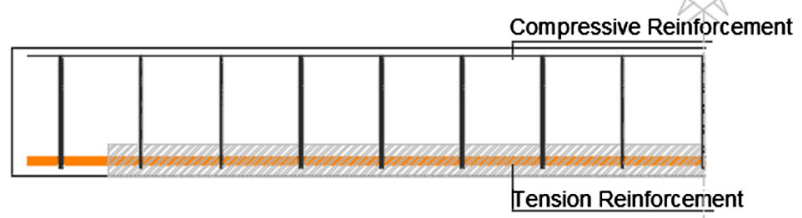

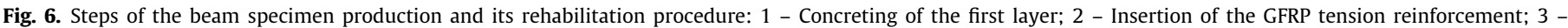
Concreting of the second layer; 4 - Rotation of the beam.

The beams were produced at $\mathrm{LREC}^{1}$ in an upside-down position in order to facilitate the operations to simulate the rehabilitation procedure. In the first phase of their production the specimens were concreted from the top until the tension reinforcement level. The support areas were fully concreted in this phase to simulate the intersection with an existent $0.30 \times 0.25 \mathrm{~m}^{2}$ column. The main stages of this phase are presented in Fig. 7. The formworks were filled with concrete until it reached the desired level, which was $0.10 \mathrm{~m}$ from the top for REHABSTEEL and REHABGFRP1 and $0.15 \mathrm{~m}$ for REHABGFRP2. These values were considered to ensure that the new reinforcement would be properly covered by the rehabilitation concrete layer. Then moulds were positioned at the ends of the beams and these areas were filled with concrete until the top. These negatives were introduced in the specimens to avoid the drilling of the holes of the corroded reinforcement, which had to be made in a real situation.

The mould was removed after the hardening of the concrete, the holes for the new reinforcement were enlarged and the surface was pricked with a pneumatic hammer. The tension reinforcement bars

\footnotetext{
${ }^{1}$ LREC - Regional Laboratory of Civil Engineering
}

were introduced and the holes were sealed with a two-component epoxy resin. After mixing the components the resin was applied with a silicone spray to prevent voids. After this, the rehabilitation layer was concreted in such a way as to ensure the proper cover of the reinforcement. These stages are presented in Fig. 8. Before testing, the beams were rotated to the correct position (Fig. 6).

\subsubsection{Tests loading history}

All beam specimens were tested in a three-point bending test, with a free span of $4.0 \mathrm{~m}$ and the load was applied using a $1500 \mathrm{kN}$ hydraulic actuator. The actuator, the load cells, the strain gauges and the LVDTS were connected to a data acquisition system to continuously monitor and record the values. The loading was controlled by force and its history up to failure was divided into $5 \mathrm{kN}$ steps to allow a beam inspection at the predicted load values of the different stages of the beam's behaviour: the cracking load, the mean and the design values of the yielding and failure loads. Pictures were taken and the development of the cracking pattern was visually observed and marked on the side of each beam. In each test, three total discharges were considered to assess the deflection recover ability of the beam. The first was at $10 \mathrm{kN}$ and 

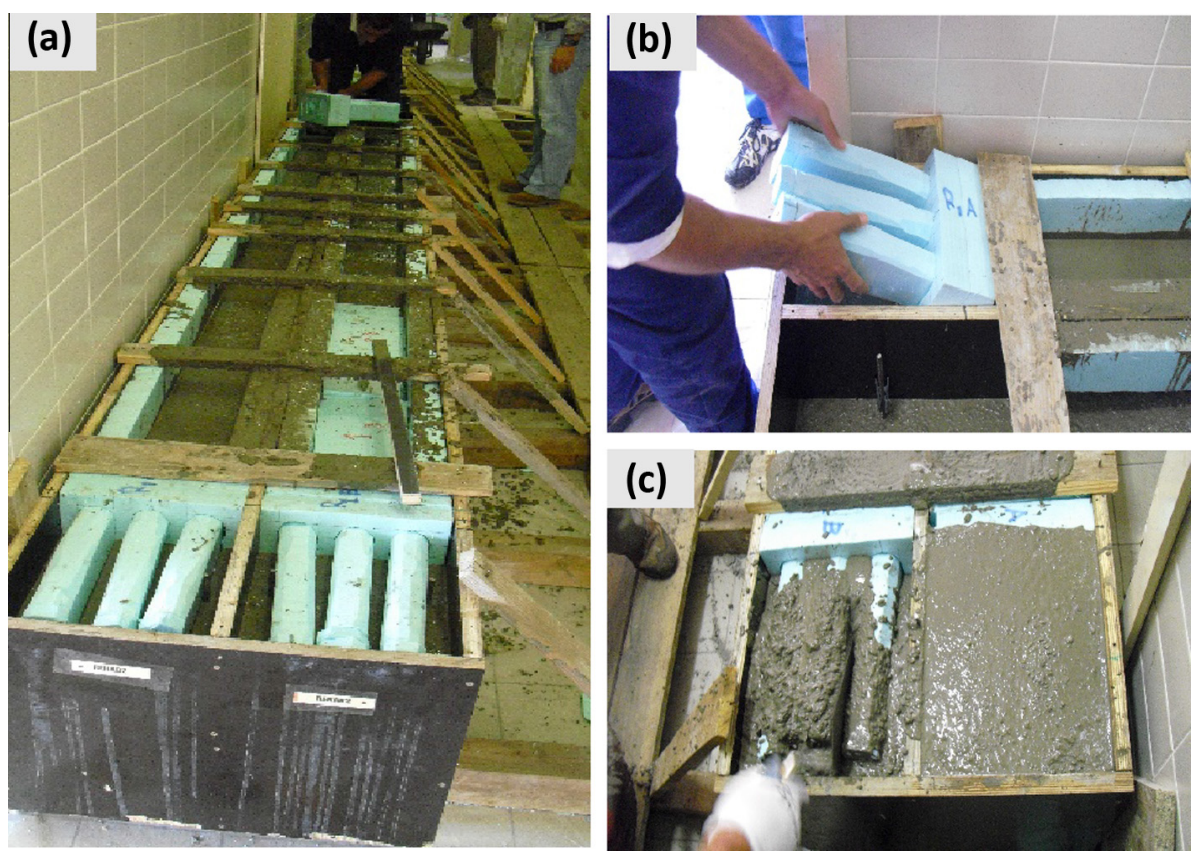

Fig. 7. First stage of the specimen's production: (a) filling the formworks with concrete until it reaches the tension reinforcement level; (b) insertion of the negatives at the supports; (c) filling with concrete the support areas.
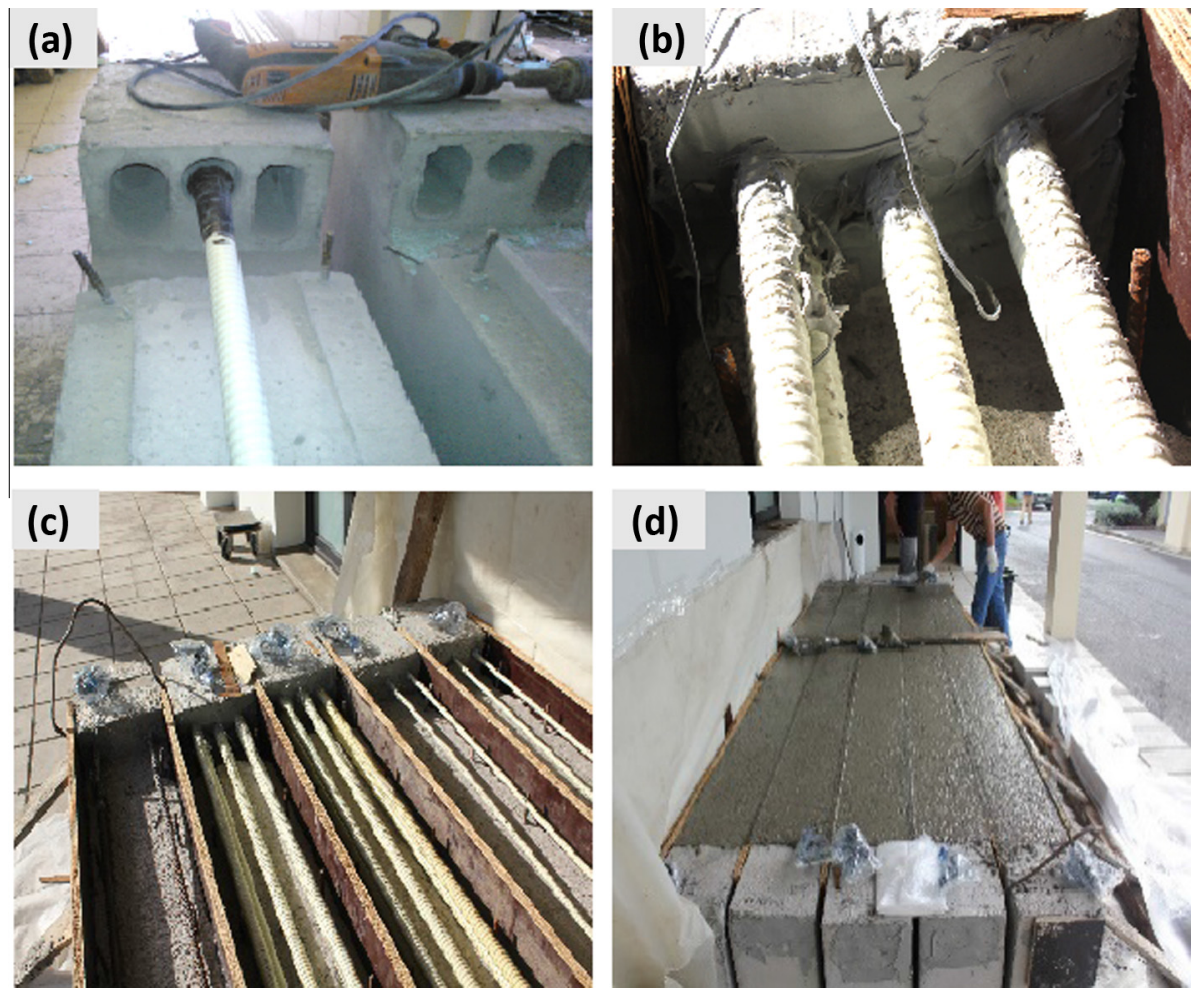

Fig. 8. Steps of the rehabilitation stage: (a) enlargement of the holes, concrete surface pricking and reinforcement insertion; (b) and (c) sealing of the anchorage holes; (d) rehabilitation layer concreting.

full recovery was predicted since at this value the beams were not expected to be cracked. The second and third discharges were near the predicted values of the cracking and the service loads respectively of each specimen. The cracking load was also determined from the loss of stiffness on the load-deflection relationships obtained from the tests. The service load of each beam was considered to be $30 \%$ of its flexural capacity, as suggested by some researchers [2].

\section{Results and discussion}

\subsection{Theoretical background}

Before the tests a theoretical prediction of the cracking moment, the failure moment and the mid-span deflection values for each beam was made based on the ACI 440.1R-06 [12], FIB-40 [13] and EC2 [27]. The equations used for the theoretical 
Table 7

Equations used in prediction values.

\begin{tabular}{|c|c|}
\hline \multirow{2}{*}{\multicolumn{2}{|c|}{ Cracking moment and deflection }} \\
\hline & \\
\hline$M_{c r}=\frac{2 \cdot\left(0.62 \sqrt{f_{c}^{\prime}}\right) I_{g}}{h}$ & (1) \\
\hline$M_{c r}=f_{c t m} \frac{b h^{2}}{6}$ & $(2)$ \\
\hline$I_{e}=\left(\frac{M_{c r}}{M_{a}}\right)^{3} \beta_{d} I_{g}+\left[1-\left(\frac{M_{c r}}{M_{a}}\right)^{3}\right] I_{c r} \leqslant I_{g}$ & (3) \\
\hline$\beta_{d}=0.2\left(\frac{\rho_{f}}{\rho_{f_{j}}}\right) \leqslant 1.0$ & $(4)$ \\
\hline Flexural capacity & \\
\hline$\rho_{f}=\frac{A_{f}}{b d}$ & $(5)$ \\
\hline$\rho_{f b}=0.85 \cdot \beta_{1} \frac{f_{c}^{\prime}}{f_{f_{f u}}} \frac{E_{f} \varepsilon_{f u}}{E_{f c u} f_{f u}}$ & $(6)$ \\
\hline$\beta_{1}=\left\{\begin{array}{c}0.85+\left[\frac{-0.05}{7}\left(f_{c}^{\prime}-28\right)\right] \text { for } f_{c}^{\prime} \geqslant 28 \mathrm{MPa} \\
0.85 \text { for } f_{c}^{\prime}<28 \mathrm{MPa}\end{array}\right.$ & $(7)$ \\
\hline$\rho_{f b}=\frac{0.81\left(f_{c m}\right) \varepsilon_{c u}}{f_{f k}\left(\frac{f_{f k}}{f_{f}}+\varepsilon_{c u}\right)}$ & $(8)$ \\
\hline$M_{n}=\rho_{f} f_{f}\left(1-0.59 \frac{\rho_{f} f_{f}}{f_{c}^{\prime}}\right) b d^{2}$ & (9) \\
\hline$f_{f}=\left(\sqrt{\frac{\left(E_{f} \varepsilon_{c u}\right)^{2}}{4}+\frac{0.85 \beta_{1} f_{c}^{\prime}}{\rho_{f}} E_{f} \varepsilon_{c u}}-0.5 E_{f} \varepsilon_{c u}\right) \leqslant f_{f u}$ & (10) \\
\hline$M_{u}=f_{c d} b d^{2}\left(0.8 \frac{\varepsilon_{c u}}{\varepsilon_{f}+\varepsilon_{c u}}\right)\left(1-\frac{0.8}{2} \frac{\varepsilon_{c u}}{\varepsilon_{f}+\varepsilon_{c u}}\right)$ forf $f_{c k} \leqslant 50 \mathrm{MPa}$ & (11) \\
\hline 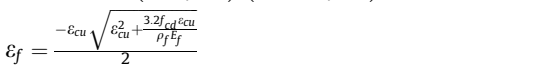 & (12) \\
\hline Mid-span strain & \\
\hline$\varepsilon=\frac{M}{0.9 d A E}$ & (13) \\
\hline
\end{tabular}

predictions are indicated in Table 7. The obtained values are presented in the tables within the experimental results in Section 3.2 to establish a comparison.

\subsection{Experimental results and comparison with values of predictions}

\subsubsection{Deflection at service load}

An actual beam needing rehabilitation due to the corrosion of the steel reinforcement is already cracked due to this problem and due to the service load. However, in the present research work it was assumed that the steel corrosion only occurred at the bottom of the beam, which is usually the most exposed side to the aggressive environment, and therefore the consequent concrete delamination did not occur in the whole element. Since the removed tensile concrete height was $0.10 \mathrm{~m}$ and $0.15 \mathrm{~m}$, which corresponds to $25 \%$ and $37.5 \%$ of the beam total height respectively, it is supposed that all the cracked concrete is located in this area in the majority of the cases that are worth being repaired.
Therefore it is assumed that the repaired beam begins its performance from an uncracked state and the cracking moment is the boundary between this state and the cracked state.

Fig. 9 shows the ratio between the experimental-to-predicted values of the deflection at service load. The results of the deflection at service load are also presented in Table 8 . Theoretical predictions of deflection were calculated using Equations from (1) to (4), $I_{e}$, modified by the factor $\beta_{d}$ of the ACI 440.1R-06 [12]. To predict the deflection of a steel RC beam the ACI 318 [17] formulation was used.

It is possible to conclude that the main objective of the REHABGFRP2 beams was achieved, which was having the same deflection as the reference beam (REF) $(5.00 \mathrm{~mm})$, since the REHABGFRP2A beam presented almost the same value $(5.15 \mathrm{~mm})$ and the average of both beams was $5.84 \mathrm{~mm}$. As expected, the average deflection of the REHABGFRP1 beams was $9.8 \mathrm{~mm}$ which was almost twice of the REF beam.

\subsubsection{Flexural capacity and failure modes}

The loading capacity of the rehabilitated beams with GFRP bars was also predicted according to ACI 440.1R-06 [12] and FIB 40 [13] (proposed modifications to EC2) and the results are presented in Table 9. The REHABGFRP beams were designed as overreinforced to fail by concrete crushing, whereas the REF and the REHABSTEEL beams were designed as under-reinforced to fail by steel yielding.

The failure mode by concrete crushing is the usual design concept for concrete reinforced with FRP according to ACI 440.1R-06 [12]. Several authors $[13,14,34]$ have studied the bending behaviour, and observed that the concrete crushing failure provides a better energy absorption, better member deformability, more gradual failure, lower deflections and crack widths and a relatively more ductile failure. For the theoretical predictions, firstly the reinforcement ratio, $\rho_{f}$, calculated from Eq. (5) is compared with the balanced reinforcement ratio, $\rho_{f b}$, which in the ACI $440.1 \mathrm{R}-06$ [12] is given by Eq. (6) where $\beta_{1}$ is a coefficient obtained by [12]. With the same principle, Pilakoutas et al. [35] derived Eq. (8) from EC2 [27] for the balanced reinforcement ratio. The balanced failure is the case when the strains in the concrete and in the GFRP bars reach their limits simultaneously and the balanced reinforcement ratio is the limit between the compression and tension failure. For the concrete failure, the ACI 440.1R-06 [12] uses Eq. (7) to calculate the moment capacity prediction (nominal moment), $M_{n}$, of a rectangular concrete cross-section. The term $f_{f}$ is the FRP reinforcement tension stress [MPa] obtained from Eq. (8). The FIB 40

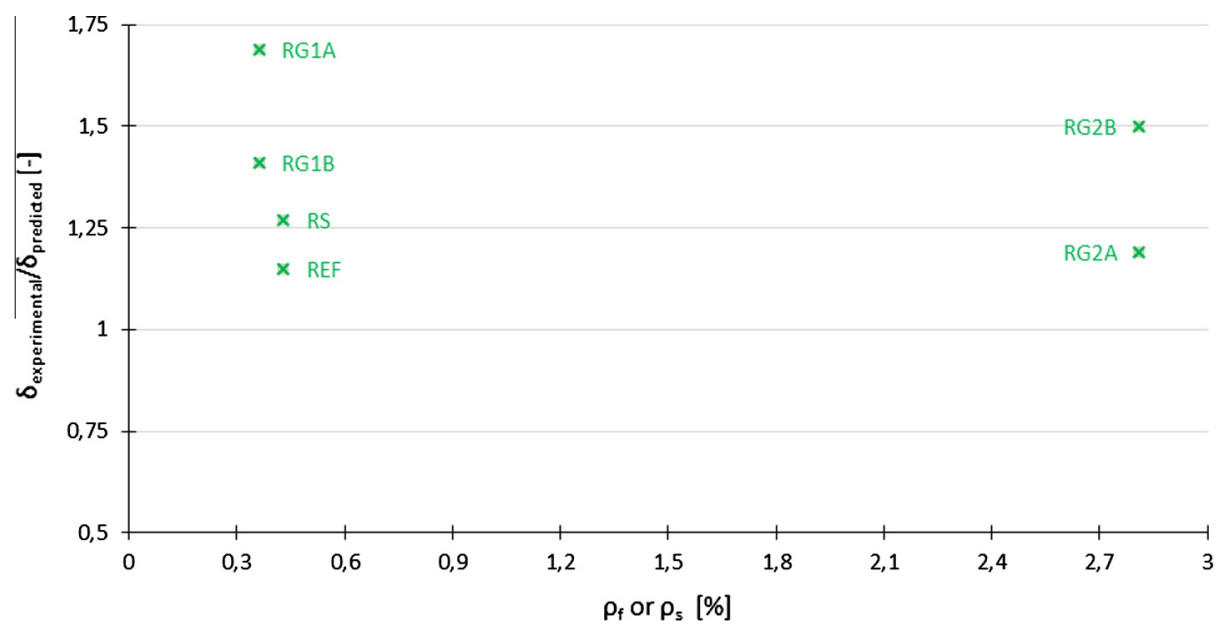

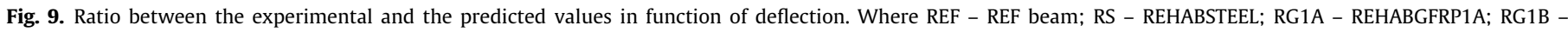
REHABGFRP1B; RG2A - REHABGFRP2A; RG2B - REHABGFRP2B. 
Table 8

Summary of the experimental-to-predicted values of the deflection at service load.

\begin{tabular}{|c|c|c|c|c|c|}
\hline \multirow[t]{2}{*}{ Beam } & \multirow{2}{*}{$\begin{array}{l}\text { Service load } 0.30 \mathrm{M}_{\mathrm{u}} \\
{[\mathrm{kN}]}\end{array}$} & \multicolumn{4}{|c|}{ Service deflection, $\delta$} \\
\hline & & $\begin{array}{l}\text { Experimental } \\
{[\mathrm{mm}]}\end{array}$ & & $\begin{array}{l}\mathrm{ACI} \\
{[\mathrm{mm}]}\end{array}$ & $\delta^{\exp } / \delta^{\text {pred }}$ \\
\hline $\begin{array}{l}\text { REF } \\
\text { REHABSTEEL }\end{array}$ & 30.00 & $\begin{array}{l}5.00 \\
5.50\end{array}$ & 5.25 & 4.34 & $\begin{array}{l}1.15 \\
1.27\end{array}$ \\
\hline $\begin{array}{l}\text { REHABGFRP1 A } \\
\text { REHABGFRP1 B }\end{array}$ & 30.00 & $\begin{array}{l}10.65 \\
8.93\end{array}$ & 9.80 & 6.32 & $\begin{array}{l}1.69 \\
1.41\end{array}$ \\
\hline $\begin{array}{l}\text { REHABGFRP2 A } \\
\text { REHABGFRP2 B }\end{array}$ & $30.00^{\mathrm{a}}$ & $\begin{array}{l}5.15 \\
6.52\end{array}$ & 5.84 & 4.32 & $\begin{array}{l}1.19 \\
1.50\end{array}$ \\
\hline
\end{tabular}

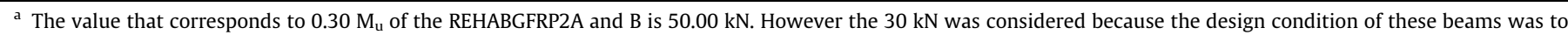
have the same deflection as the REFREHAB at its service load.

Table 9

Summary of the experimental and the predicted ultimate moments for the tests with the corresponding design values.

\begin{tabular}{|c|c|c|c|c|c|c|c|c|c|c|c|c|c|}
\hline \multirow[t]{3}{*}{ Beam } & \multirow{3}{*}{$\begin{array}{c}\rho_{\mathrm{fb}} \\
\% \\
\%\end{array}$} & \multirow{3}{*}{$\begin{array}{l}\rho_{\mathrm{f}} \text { or } \rho_{\mathrm{s}} \\
\%\end{array}$} & \multirow{2}{*}{\multicolumn{3}{|c|}{ Experimental }} & \multicolumn{4}{|c|}{ Predicted } & \multicolumn{4}{|l|}{ Design } \\
\hline & & & & & & \multicolumn{2}{|l|}{$\overline{\mathrm{ACI}}$} & \multicolumn{2}{|c|}{ FIB $40 / E C 2^{a}$} & \multicolumn{2}{|l|}{$\mathrm{ACI}$} & \multicolumn{2}{|c|}{ FIB $40 / E C 2^{a}$} \\
\hline & & & $\begin{array}{l}\mathrm{M}_{\mathrm{u}} \\
{[\mathrm{kNm}]}\end{array}$ & $\begin{array}{l}\mathrm{M}_{\text {Mean }} \\
{[\mathrm{kNm}]}\end{array}$ & $\begin{array}{l}\delta \\
{[\mathrm{mm}]}\end{array}$ & $\begin{array}{l}\mathrm{M}_{\mathrm{u}} \\
{[\mathrm{kNm}]}\end{array}$ & exp/pred & $\begin{array}{l}\mathrm{M}_{\mathrm{u}} \\
{[\mathrm{kNm}]}\end{array}$ & exp/pred & $\begin{array}{l}\mathrm{M}_{\mathrm{u}} \\
{[\mathrm{kNm}]}\end{array}$ & exp/pred & $\begin{array}{l}\mathrm{M}_{\mathrm{u}} \\
{[\mathrm{kNm}]}\end{array}$ & exp/pred \\
\hline REF & & 0.429 & 94.1 & 91.9 & 90.5 & 89.4 & 1.05 & 88.7 & 1.06 & $(-)$ & & $(-)$ & \\
\hline REHABSTEEL & & & 89.8 & & 98.9 & & 1.00 & & 1.01 & $(-)$ & & $(-)$ & \\
\hline REHABGFRP1A & 0.27 & 0.362 & 94.0 & 89.9 & 89.3 & 87.4 & 1.08 & 92.1 & 1.02 & 70.8 & 1.33 & 58.3 & 1.61 \\
\hline REHABGFRP1B & & & 85.9 & & 66.0 & & 0.98 & & 0.93 & & 1.21 & & 1.47 \\
\hline REHABGFRP2A & 0.26 & 2.81 & 181.5 & 193.9 & 59.1 & 205.2 & 0.94 & 208.6 & 0.87 & 136.2 & 1.33 & 125.7 & 1.44 \\
\hline REHABGFRP2B & & & 206.2 & & 67.0 & & 1.00 & & 0.99 & & 1.51 & & 1.64 \\
\hline
\end{tabular}

a It was used the formulas of the EC2 or the FIB40, whether the prediction/design result was for the reinforced concrete beam with steel or GFRP bars, respectively.

[13] suggests that the ultimate moment resistance, $M_{u}$, can be obtained by Eq. (9), where $\varepsilon_{f}$ is the FRP reinforcement tensile strain [MPa], which is given by Eq. (10).

Concerning the beams with bottom longitudinal steel reinforcement, the REHABSTEEL beam presented a load-carrying capacity $(89.81 \mathrm{kN})$ only $4.5 \%$ lower than the REF beam (94.06 kN), which proves that the rehabilitation solution works and is not affected by the new concrete layer.

The main objective of the REHABGFRP1 beams was achieved, which was having the same load capacity as the reference beam (REF) (94.06 kN), since the REHABGFRP1A beam presented the exact same value $(94.03 \mathrm{kN})$ and the average of both REHABGFRP1A and B beams ( $89.94 \mathrm{kN})$ was only $4.4 \%$ lower.

Comparing the rehabilitated beams with GFRP bars (REHABGFRP1 and REHABGFRP2), the $\rho$ increase of approximately eight times, from $0.362 \%$ to $2.810 \%$ corresponded to an average increase of $215.5 \%$ in loading capacity, from $89.94 \mathrm{kNm}$ to 193.85 $\mathrm{kNm}$. On the other hand, as demonstrated in the previous section, the REHABGFRP2 beams achieved their design objective of having the same deflection as the reference beam.

The experimental to predicted values ratio using FIB 40 [13] was non-conservative for REHABGFRP1B and for REHABGFRP2A (Fig. 10), whereas the $\mathrm{ACI} 440.1 \mathrm{R}-06$ [12] predictions were conservative. One reason for the differences between ACI 440.1R-06 [12] and FIB 40 [13] predictions is the fact that the ultimate concrete compression strain is considered as $3.0 \%$ and $3.5 \%$, respectively [2].

The ultimate loads from a design point of view, considering the safety factors, are shown in Table 9. In general, it is possible to conclude that the beams had an ultimate capacity on tests that ranged from 1.2 to 1.5 times the design ultimate load value of ACI $440.1 \mathrm{R}$ 06 [12] and from 1.4 to 1.7 times the design ultimate load value of FIB 40 [13].

The crack propagation of the beams during the tests was marked on one of the faces and reproduced in Fig. 11. All specimens presented bending failure modes and a detailed description is indicated in Table 10, complemented with some test pictures, shown from Figs. 12-17.

The reference beam REF had a failure mode caused by the breaking of the bottom steel reinforcement at mid-span (Fig. 12). Several flexural cracks developed along the span (Fig. 11(a)). Although these cracks were initially vertical, they started to incline in the direction of the load-point with the failure approach (Fig. 12 (a)). The failure occurred after the two central cracks reached the load-point (Fig. 12(b)).

The REHABSTEEL beam had a similar failure mode to the REF beam, with the yielding of the bottom steel reinforcement at mid-span region but followed by the crushing of the top concrete in compression (Fig. 13). The crack pattern was similar to the REF beam, differing in the fact that, close to mid-span, the cracks also developed horizontally at mid-height of bottom concrete layer, suggesting some slip of the tension reinforcement (Fig. 11 (b)). No visible slip or separation between the two concrete layers occurred in this beam (Fig. 13(b)-(d)).

Both REHABGFRP1A and B beams had similar behaviour until failure. The cracks appeared along the entire span, propagating from the bottom concrete layer to the other in the direction of the load point. Horizontal cracks at the bottom reinforcement level started to appear with the load increase. A partial separation between the two concrete layers was also detected, which started at the mid-span zone and propagated into the support direction (Fig. 11(c) and (d)). In these two cases, the failure was caused by the crushing of the top concrete in compression at the load point, followed by the separation of the concrete layers which caused some spalling of the bottom concrete layer (Figs. 14 and 15).

The REHABGFRP2A and B beams also had a similar crack pattern and behaviour until failure. As the load increased, horizontal cracks at the tension reinforcement level and the separation between the two concrete layers were detected. These two phenomena started at the mid-span zone and progressed to the supports, which 


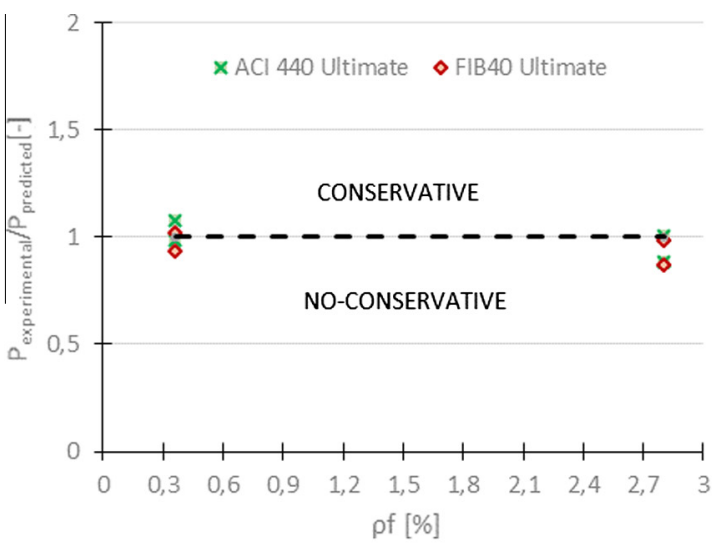

(a)

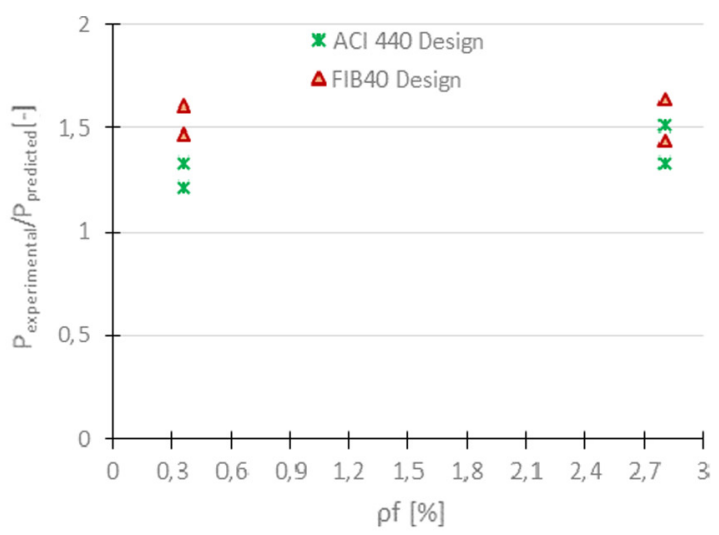

(b)

Fig. 10. GFRP beams ratio between the experimental and the predicted values as a function of: (a) Experimental ultimate moment; (b) Design moment.
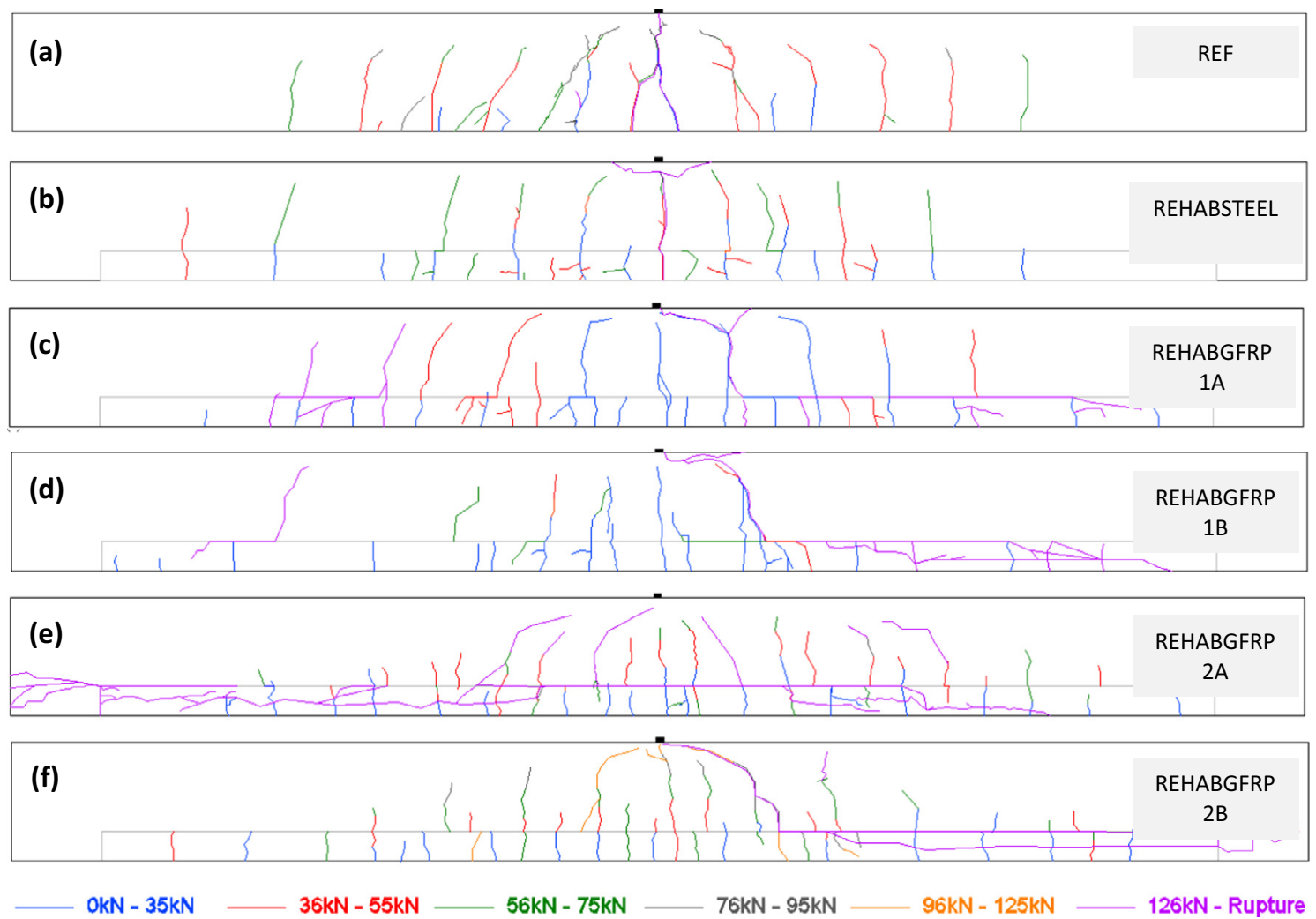

Fig. 11. Main cracking at failure: (a) REF; (b) REHABSTEEL; (c) REHABGFRP1A; (d) REHABGFRP1B; (e) REHABGFRP2A; (f) REHABGFRP2B.

Table 10

Description of failure modes.

\begin{tabular}{|c|c|}
\hline Beam & Experimental failure mode \\
\hline REF & Yielding of tension steel \\
\hline REHABSTEEL & Yielding of tension steel and concrete crushing \\
\hline REHABGFRP1A & $\begin{array}{l}\text { Compression concrete crushing and debonding of new } \\
\text { concrete in central tension zone }\end{array}$ \\
\hline REHABGFRP1B & $\begin{array}{l}\text { Compression concrete crushing and debonding of new } \\
\text { concrete in central tension zone }\end{array}$ \\
\hline REHABGFRP2A & $\begin{array}{l}\text { Tension GFRP bars split and debonding and spalling of new } \\
\text { concrete in mid-span and supports }\end{array}$ \\
\hline REHABGFRP2B & $\begin{array}{l}\text { Tension GFRP bars split and debonding and spalling of new } \\
\text { concrete in mid-span and supports }\end{array}$ \\
\hline
\end{tabular}

contributed to the failure (Fig. 11(e) and (f)). The failure occurred mainly due to the slip of the tension GFRP bars at the support areas. Debonding and spalling of the new concrete was also observed at mid-span and supports (Figs. 16 and 17). Despite the global slip at failure between the reinforcement and the concrete, no visible debonding between the GFRP bars and the resin at the supports area was found. The resin stayed bonded to the reinforcement and slipped from the concrete (Fig. 16(d)).

A failure due to the slip of the tension reinforcement highlights the lack of anchorage length. However, it is important to mention that despite the failure occurred due to the slip of the tension GFRP bars at the supports, it did not compromise the desired behaviour and bending capacity. These two beams supported a load 2.5 times 


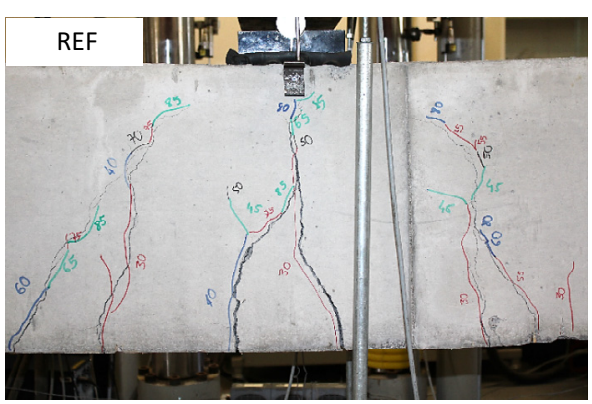

(a)

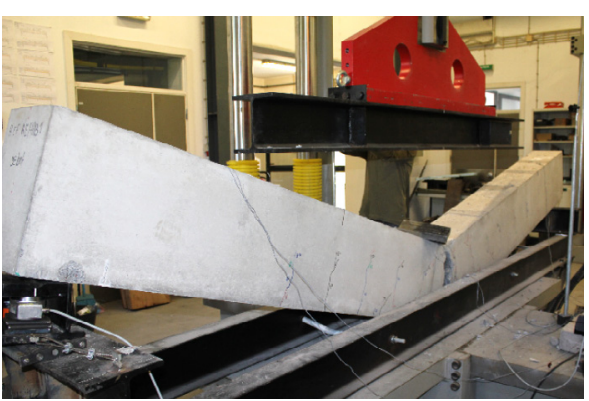

(b)

Fig. 12. REF beam failure: (a) immediately before; (b) after.

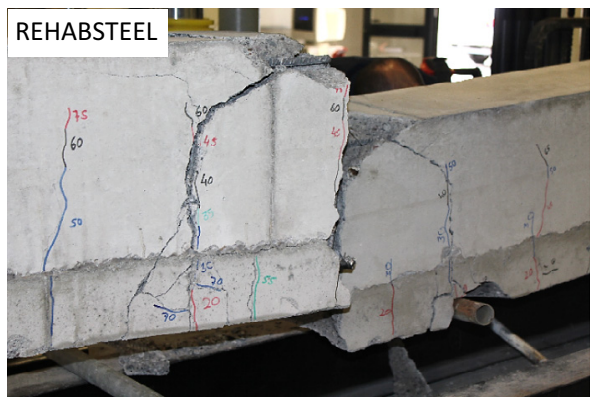

(a)

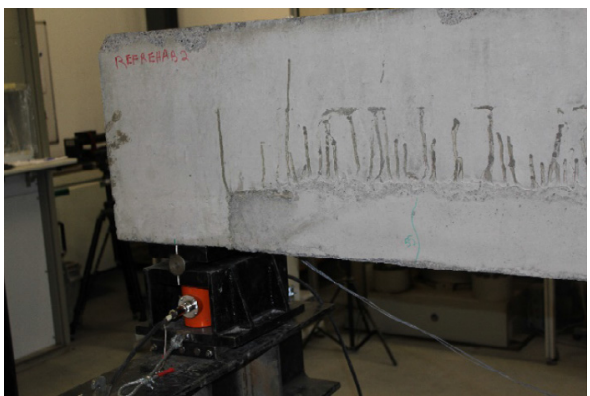

(c)

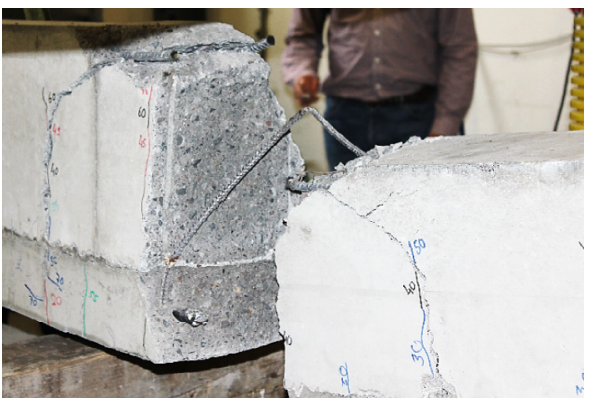

(b)

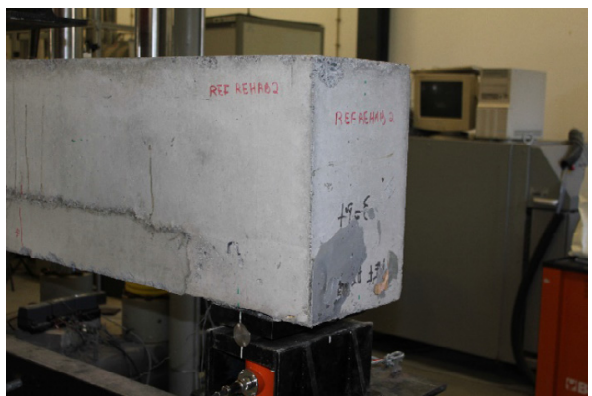

(d)

Fig. 13. REHABSTEEL beam failure: (a) at mid-span; (b) mid-span cross section detail; (c) left support; (d) right support.

greater than the original beam, and this means that as a rehabilitation solution they will never be subjected to this loading level, except if this solution is also a strengthening solution to increase the bending capacity. To the level of load corresponding to the reference beam, the support areas were in perfect condition. This is shown in Fig. 11(e) and (f), where it is possible to state by the colour scaling that the support areas only started to be affected for a load higher than $126 \mathrm{kN}$. This is also evident in Fig. 18, as the support strains only increased for loads above $150 \mathrm{kN}$.

\subsubsection{Tensile reinforcement strain}

Eq. (13) was used to estimate the bar strains at the mid-span. This formula is obtained from the equilibrium equations of the cross-section and considering only the reinforcement contribution. With a free span length of $\mathrm{L}=4.0 \mathrm{~m}$, the bending moment at midspan is equal to the applied load, $\mathrm{P}$, according to: $\mathrm{M}=\mathrm{P} * \mathrm{~L} / 4=\mathrm{P}$.

In order to study the bottom longitudinal reinforcement strains at the supports and at the mid-span, two strain gauges were glued to two bars at these positions of each beam. The load-strain relationships at the mid-span and at the supports are presented in
Figs. 18 and 19. The curves present the mean strains of the two strain gauges at each monitored cross-section.

The tensile strains at the mid-span of the steel reinforced beams (REF and REHABSTEEL) presented a three stage behaviour development until failure: the elastic, the cracked and the yielded stages. On the other hand, the GFRP reinforced beams only presented the elastic and the cracked stages.

At maximum load capacity, the mean value of strains at midspan for REHABGFRP1A and for REHABGFRP1B were, respectively, $12.28 \%$ and $12.48 \%$. Theoretical strains were of $12.51 \%$ and $13.41 \%$ respectively for REHABGFRP1A and for REHABGFRP1B at mid-span for the maximum load.

Although for REHABGFRP2A and REHABGFRP2B there was a strain gauge glued on the centre rebar and the other on the outside rebar, the strain values were similar and the mean maximum value was $3.75 \%$ at the maximum load capacity for REHABGFRP2A and $4.35 \%$ for REHABGFRP2B. Theoretical strains were of $3.66 \%$ and $4.16 \%$ respectively for REHABGFRP2A and for REHABGFRP2B.

Comparing REHABGFRP1A and B and REHABGFRP2A and B relationships, it is possible to see that increasing the GFRP ratio 


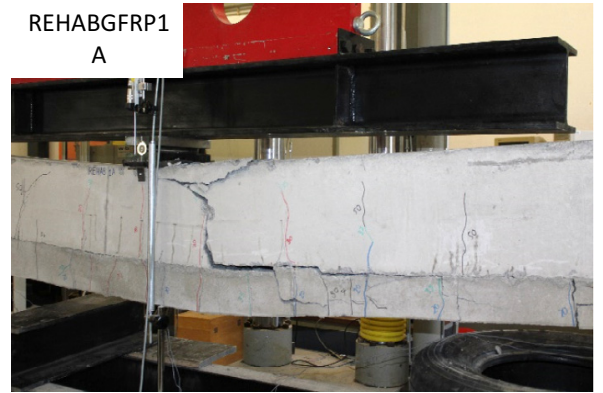

(a)

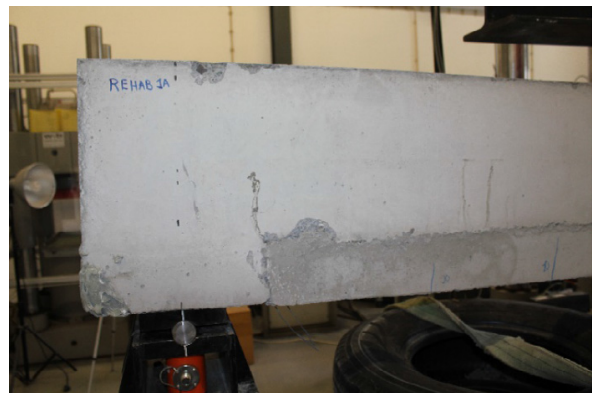

(c)

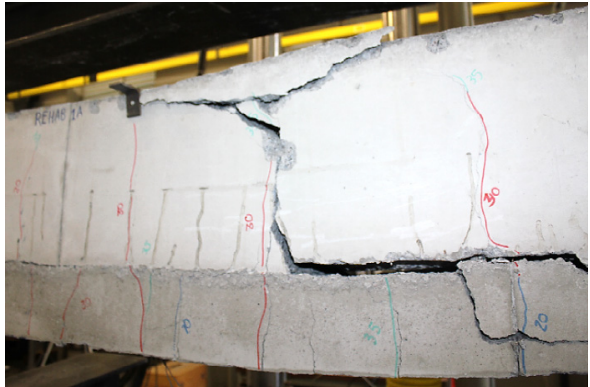

(b)

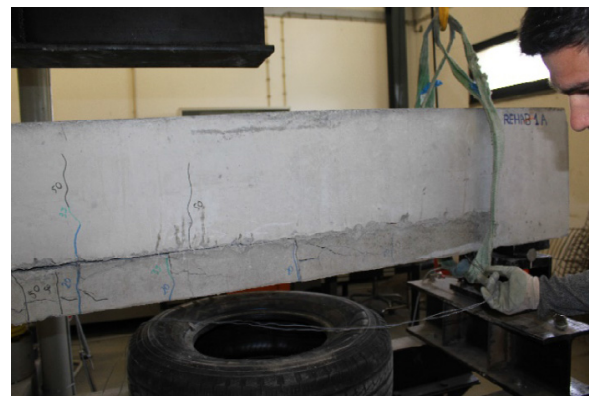

(d)

Fig. 14. REHABGFRP1A beam failure: (a) general view; (b) mid-span detail; (c) left support; (d) right support.

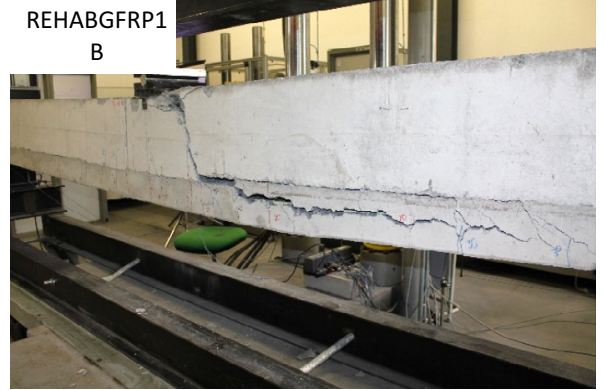

(a)

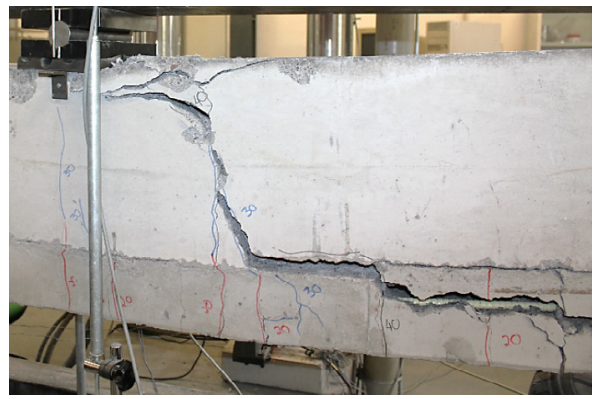

(c)

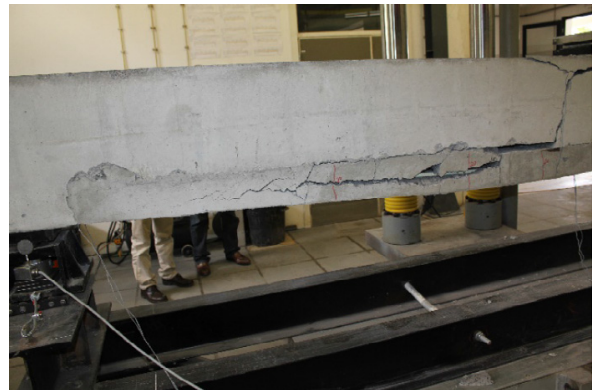

(b)

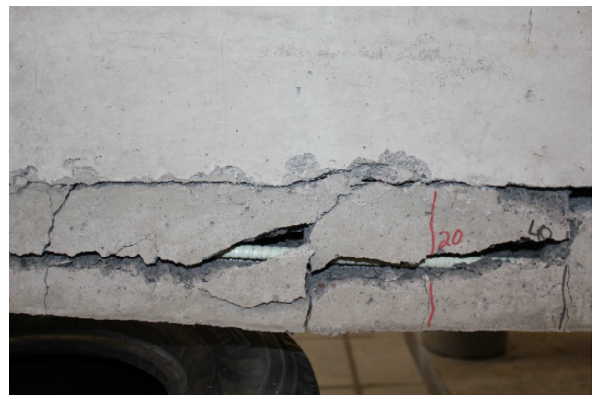

(d)

Fig. 15. REHABGFRP1B: (a) front general view; (b) back general view mid-span detail; (d) concrete layers detail.

decreases the strain in GFRP reinforcement for the same load level. REF, REHABSTEEL, REHABGFRP1 A and B had similar maximum load capacity and reinforcement area, and in general exhibit similar strains. Strains in REHABGFRP2 A and B were significantly lower than in REF and REHABSTEEL, although for regulations, they would have the same behaviour for deflections.

At the considered service load representing $30 \%$ of the ultimate load capacity, mid-span reinforcement average strain, at first load cycle, was $2.40 \%$ for REF and REHABSTEEL beams, $4.02 \%$ for REHABGFRP1A and $3.45 \%$ for REHABGFRP1B, and $0.40 \%$ for REHABGFRP2. The higher the reinforcement ratio the lower the reinforcement strains will be. Predicted values were of $4.37 \%$ and $0.6 \%$, respectively for REHABGFRP1 and REHABGFRP2.

For REF, there is a significant growth of the strains at $20 \mathrm{kN}$. This effect was not verified for REHABSTEEL. This difference in 


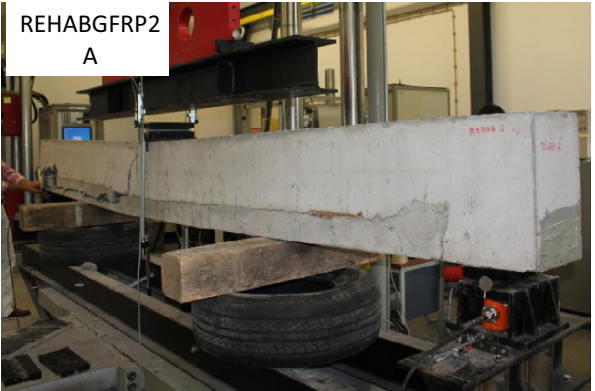

(a)

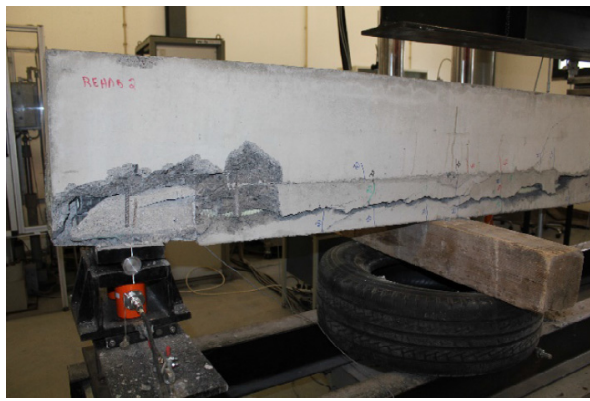

(c)

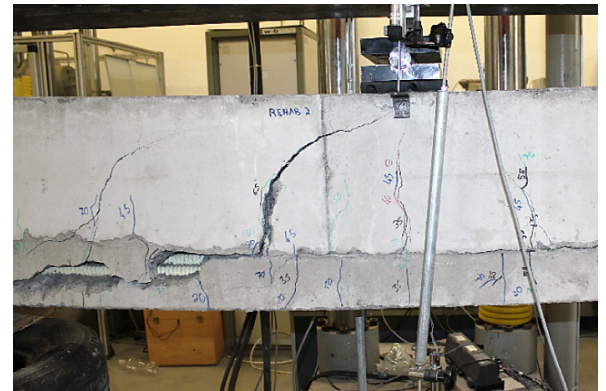

(b)

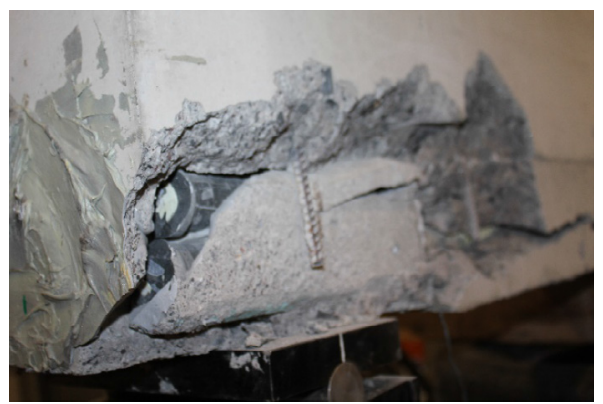

(d)

Fig. 16. REHABGFRP2A: (a) general view; (b) mid-span detail; (c) support detail; (d) reinforcement slip detail.

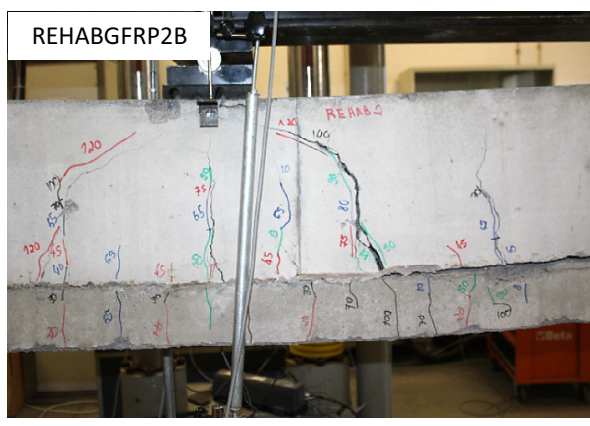

(a)

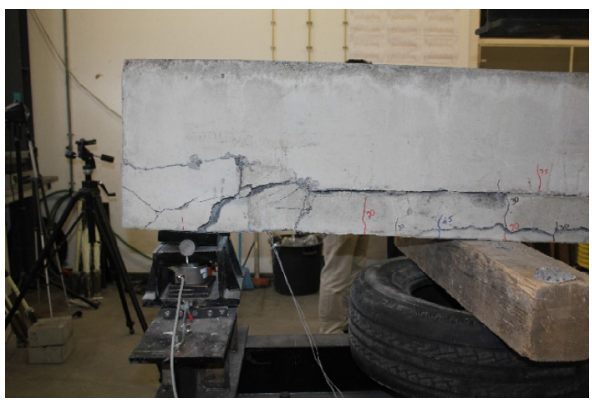

(c)

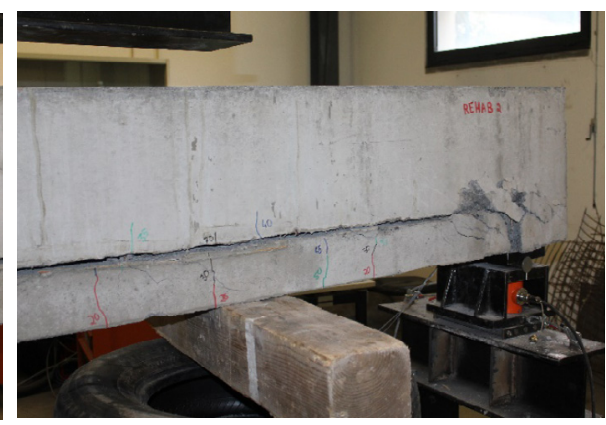

(b)

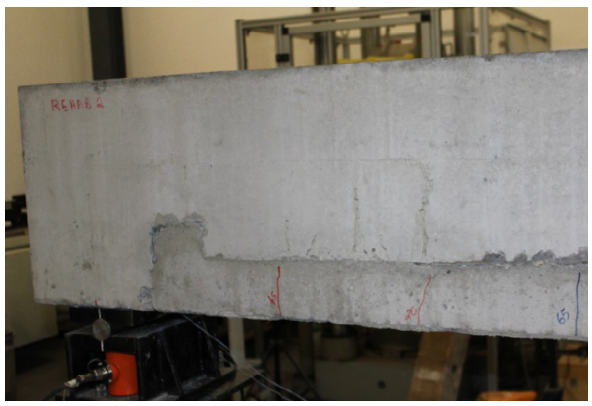

(d)

Fig. 17. REHABGFRP2B: (a) mid-span detail; (b) right support front detail; (c) right support back detail; (d) left support detail.

behaviour can be explained by the fact that measured strains are point values from a specific location of the reinforcement. If the strains were measured over a crack, the values will be affected by the "localized" increase in the reinforcement strain.

At the supports of the steel reinforced beams, the maximum strain was $0.12 \%$ at maximum load capacity. For REHABGFRP1A and REHABGFRP1B the maximum strain value was $0.15 \%$. For REHABGFRP2A and REHABGFRP2B from $150 \mathrm{kN}$ of load, strain values had a faster increase, which is noticeable by the change in the slope of the curve. Although this change gives the curve a yielding appearance graphically, it corresponds to the detachment of the concrete near the supports. It is important to state that this load level corresponds to the short-term load $\left(\mathrm{F}_{\text {head }}\right)$ which according to the manufacturer can be anchored by the end heads [30]. The maximum strain value was 3.35\%. The high level of strains at the supports shows insufficient anchorage length of the bars, 


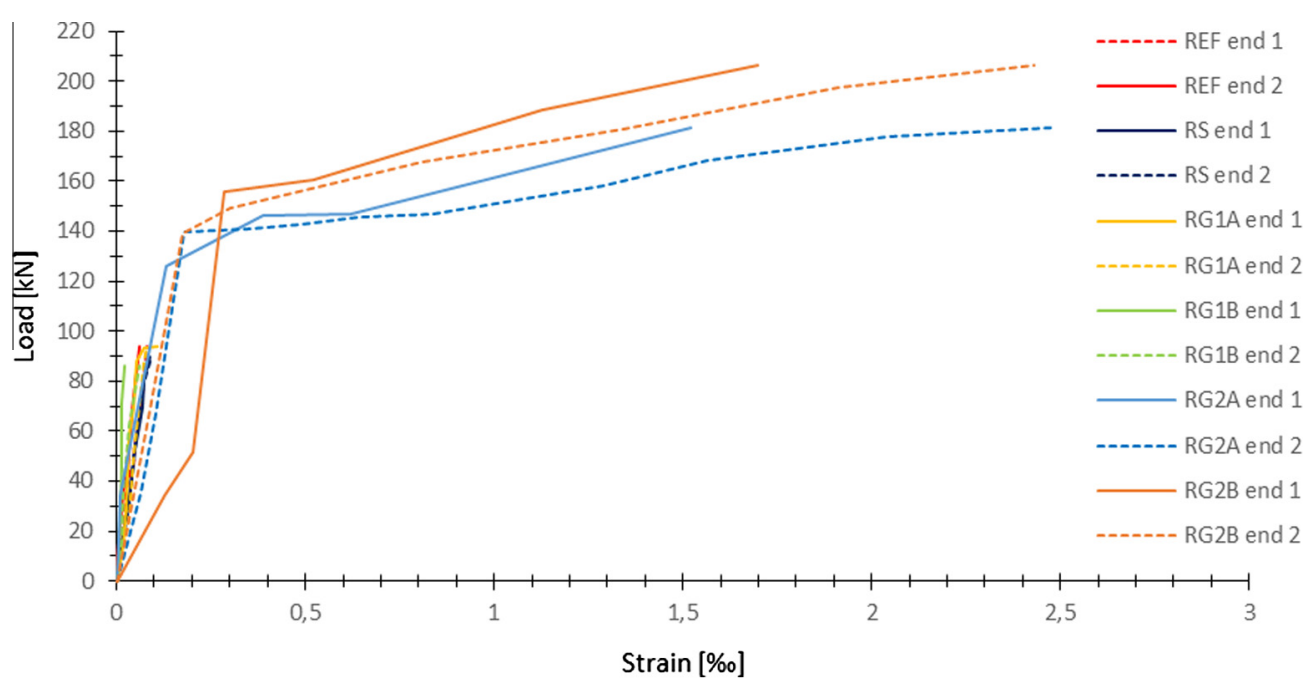

Fig. 18. Bottom reinforcement mean tensile strain of each beam at the supports (end 1 and 2).

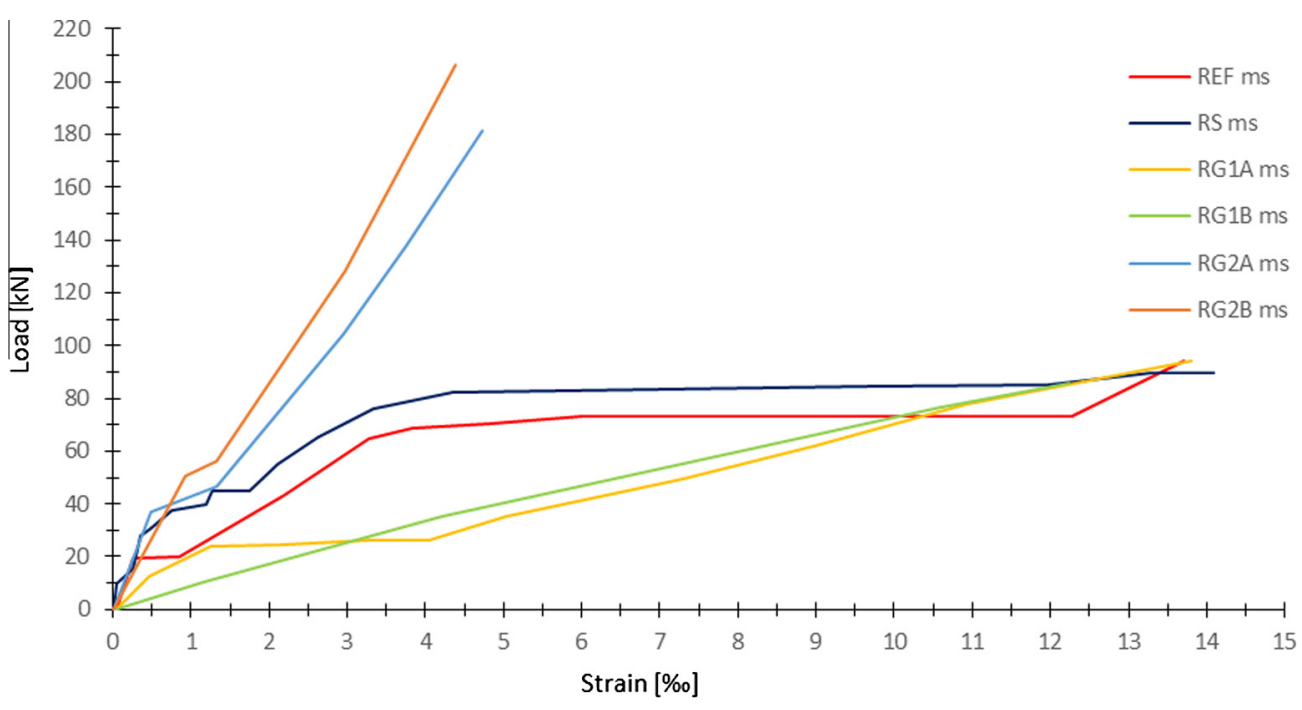

Fig. 19. Bottom reinforcement mean tensile strain of each beam at the mid-span (ms).

resulting in the failure of the support zones of these two beams when the concrete is not able to bond the high force developed at the end of the GFRP bars. The mean of reinforcement strain at supports from the side of beam that failed is indicated in Table 11. For these values the total anchorage load (F) was calculated. Subtracting the short-term load from this load $\left(F_{\text {head }}\right)$ which can be anchored by the end heads, and considering the value of bond given by the manufacturer, the anchorage length needed to prevent the failure was calculated at $0.32 \mathrm{~m}$.

\subsubsection{Deflection behaviour}

The load-deflection at mid-span curves are shown in Figs. 20 and 21. Fig. 20 shows a comparison between the four groups.

Table 11

Mean load and anchorage length at failure side of REHABGFRP2 beams.

\begin{tabular}{llll}
\hline Beam & $\begin{array}{l}\text { Mean strain, } \varepsilon \\
(\%)\end{array}$ & $\begin{array}{l}\text { Total load, F } \\
(\mathrm{kN})\end{array}$ & $\begin{array}{l}\text { Anchorage length, lb } \\
(\mathrm{m})\end{array}$ \\
\hline REHABGFRP2 A & 2.48 & 390.00 & 0.31 \\
REHABGFRP2 B & 2.56 & 401.30 & 0.32 \\
\hline
\end{tabular}

Each curve of Fig. 21 represents the average deflection obtained from the two LVDTs mounted at mid-span for each beam. These curves allow the evaluation of the flexural stiffness at the various stages of the beams until failure during the tests. The steel reinforced beams, REF and REHABSTEEL, presented similar behaviour, which can be summarized in three different stages. An elastic first phase where the relationship between the load and the mid-span displacement was linear, followed by a cracked phase where the load-displacement relation was approximately linear but with a lower slope, and a third phase, which is the steel yielding phase, characterized by a rapid increase in the deflection until failure (Fig. 21(a)). Although the two curves were similar, REHABSTEEL had slightly lower flexural stiffness after the first loading cycle, a lower yielding loading point and $4.5 \%$ lower maximum load capacity. This difference can be explained by the existence of a new layer of concrete and a possible slip between these layers. The failure mode is also shown in Fig. 11.

The development of the load-displacement at mid-span curves of the REHABGFRP1A and REHABGFRP1B beams was different from the reference beams with only two distinct and approximately linear phases and no ductile behaviour. In the first elastic stage of the beams, the relationship between the load and the deflection was 


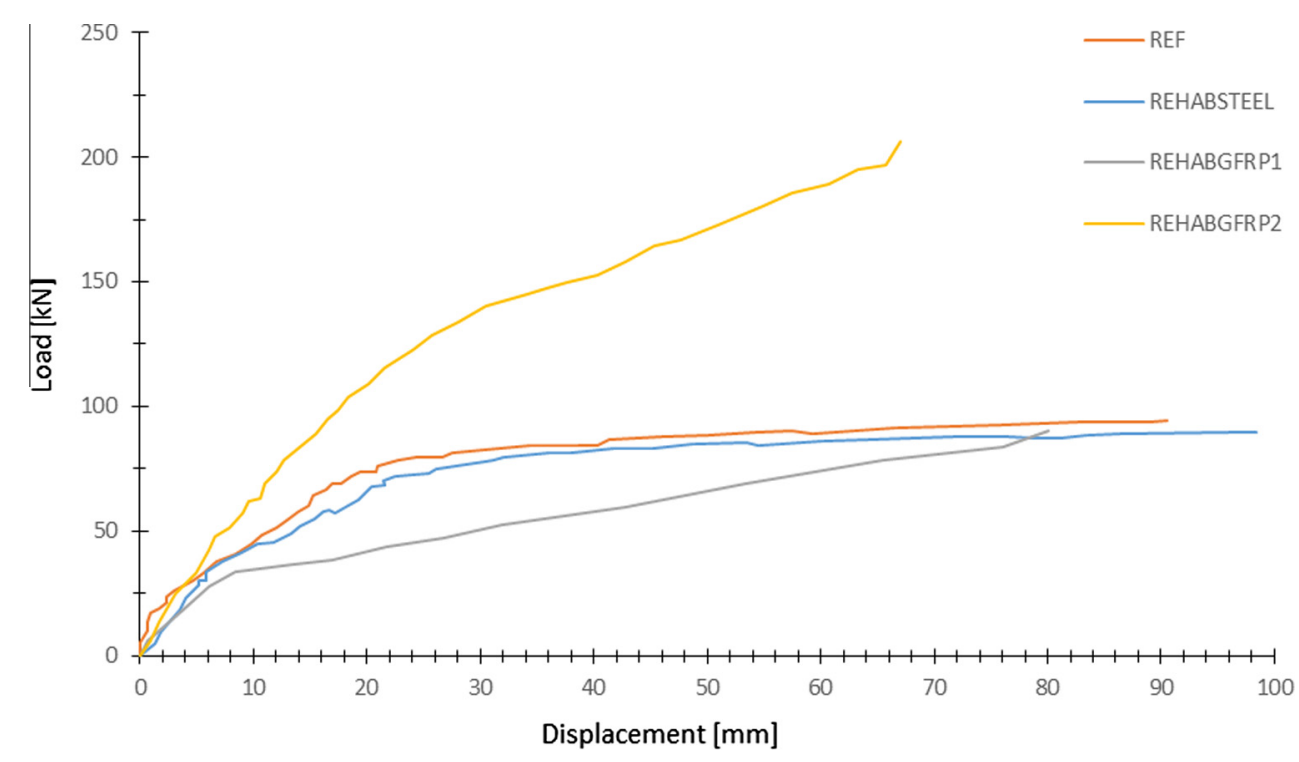

Fig. 20. Load-deflection curves at mid-span for all beams.

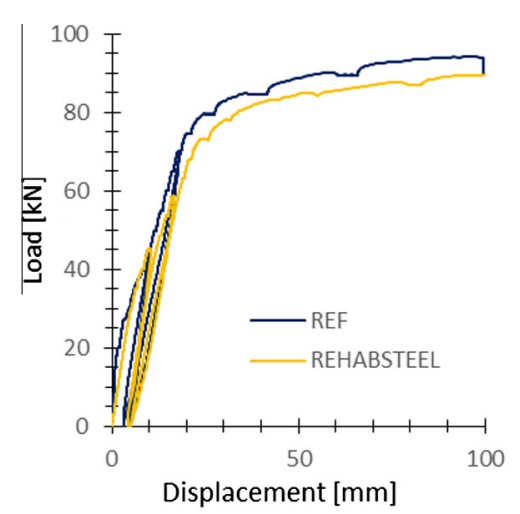

(a)

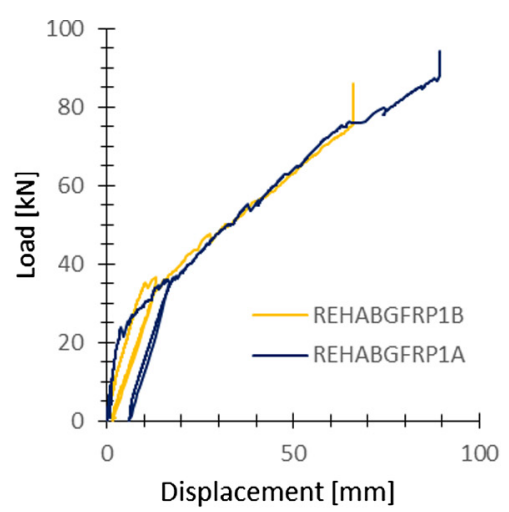

(b)

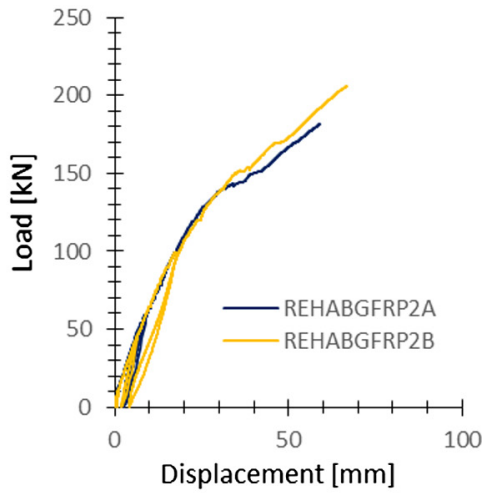

(c)

Fig. 21. Load-deflection at mid-span: (a) REF and REHABSTEEL; (b) REHABGFRP1 A and B; (c) REHABGFRP2 A and B.

linear. Then the slope of the curve decreased as a consequence of the cracking, but the relationship continued to be linear until failure.

The REHABGFRP2A and REHABGFRP2B beams had identical behaviour to the REHABGFRP1 beams. The major difference was that the transition point between the two stages was not so easily identified, since this transition was progressive, giving a non-linear aspect to the curves.

From Fig. 20, it is possible to notice qualitatively that a change in the reinforcement ratio changes the load-displacement behaviour. The lower the GFRP ratio, the higher the mid-span deflection.

Values of deflections at service load are shown in Table 8. Although the deflection of the REHABGFRP2 beams were higher than the REF beam, as expected the difference between the two values is lower than $10.0 \%$, with similar deflection values for the groups, suggesting adequacy of the prediction formulas used in both cases [12]. Although the reinforcement ratio and the ultimate capacity were close between REF and REHABGFRP1 groups, GFRP reinforced beams exhibited 1.86 times higher deflection at service. These differences are due to the lower elasticity modulus of GFRP when compared to steel (about one third). The ACI 440.1R-06 [12] underestimates the mid-span deflections. For REHABGFRP1 the experimental deflections were on average $55.0 \%$ higher than predicted, and for REHABGFRP2 34.5\%. Although this is a short-term deflection, assuming that the long-term deflection is three times higher than this value and comparing with the service limit of span/240, which corresponds to $16.7 \mathrm{~mm}$, only the reference beams and REHABGFRP2 verified the limit. This shows that service can have a greater effect than ultimate limit states when designing RC structures with GFRP reinforcement.

Deflections at ultimate limit load carrying capacity were also measured (Table 9). The REF had the highest ultimate deflection, as expected due to the ductile property of the steel reinforcement, followed by the REHABGFRP1 group and then the REHABGFRP2 group, both with no ductile behaviour.

\subsubsection{Crack development}

In order to analyse the differences of the distance between cracks and their width and length until failure, the crack development was marked on the beams with different colours after each load step. The crack pattern of all beams until failure is reproduced in Fig. 11.

The beams were initially uncracked before testing. The flexural cracks started to appear after reaching the cracking load. In general, the first cracks were vertical and developed closely to the mid-span, where the bending moment had the maximum value. As the load progressively increased, the cracks appeared along the entire span, starting vertically or at a slight angle and then 
Table 12

The mean spacing between cracks of beams.

\begin{tabular}{llll}
\hline \multirow{2}{*}{ Beam } & \multicolumn{2}{l}{ Crack spacing $(\mathrm{m})$} & \multirow{2}{*}{$\begin{array}{l}\text { Height of compression } \\
\text { zone at failure }(\mathrm{m})\end{array}$} \\
\cline { 2 - 3 } & Original layer & Rehab layer & \\
\hline REF & 0.172 & $(-)$ & 0.103 \\
REHABSTEEL & 0.221 & 0.137 & 0.064 \\
REHABGFRP1A & 0.218 & 0.109 & 0.058 \\
REHABGFRP1B & 0.231 & 0.138 & 0.063 \\
REHABGFRP2A & 0.151 & 0.141 & 0.105 \\
REHABGFRP2B & 0.164 & 0.144 & 0.121 \\
\hline
\end{tabular}

taking the load-point direction. All cracks increased in width and length until the failure of the beam.

Looking at Fig. 11, the increase in $\rho_{\mathrm{f}}$ resulted in a higher number of cracks and reduced the crack spacing. Similar behaviour was also reported by El-Nemr et al. [2]. The mean crack spacing for REF was $0.172 \mathrm{~m}$. For the rehabilitated beams, the distance between the cracks was different in the two concrete layers, with more cracks in the bottom layer (Table 12). REHABGFRP1A, REHABGFRP1B and REHABSTEEL had similar mean crack spacing. The crack spacing on the original concrete layer was approximately two times the spacing on the rehab layer. On REHABGFRP2A and B there was a better propagation of the cracks from the second layer to the first layer crack, since the crack spacing between layers was small.

Another important information that can be extracted from Fig. 11 is the distance between the top compression fibre and the cracks top. At failure, due to the high curvature of the mid-span cross-sections, this measure is approximately the position of the neutral axis or, in other words, the height of the compression zone. The results are shown in Table 12 and were determined by measuring the height of all the mid-span flexural cracks and subtracting their mean value to the height of the section. Comparing REF and REHABSTEEL, the existence of two concrete layers caused a height lessening of the compression zone. This means that there was a rise of the neutral axis in the rehabilitated beams. REHABSTEEL and REHABGFRP1A and REHABGFRP1B had similar distances. REHABGFRP2A and REHABGFRP2B also had similar values, which comparing with REHABGFRP1A and REHABGFRP1B are two times higher. It also important to mention that these values were similar to predictions done with $\mathrm{ACI} 440.1 \mathrm{R}-06$ [12] formulation, which were of $0.050 \mathrm{~m}$ for REHABGFRP1 and $0.092 \mathrm{~m}$ for REHABGFRP2.

\section{Conclusions}

This study proposed, tested and evaluated an efficient and easy to implement rehabilitation procedure that uses GFRP bars to replace the tension steel bars of deteriorated reinforced concrete beams. It is an ideal technique to repair and improve the longterm durability of the existing marine steel reinforced concrete structures with corrosion problems. The conclusions are based on the results of an experimental campaign performed with fullscale reinforced concrete beam specimens casted in two phases to simulate the replacement of the corroded and cracked concrete. Two different GFRP reinforcement ratios were tested in order to assess the behaviour of the repaired beam regarding its service and ultimate states in comparison with the original beam with steel reinforcement. The main findings of this research can be summarized as follows:

1- Although a new concrete layer with a more flexible tensile reinforcement has been introduced to the rehabilitated specimens, the construction joint was not the cause of the failure and did not compromise the serviceability and ultimate limit states of the beams.
2- Good result predictions were obtained with the formulas of the EC2 [36]/FIB40 [13] and ACI 440.1R-06 [12], which indicates that these documents can be used to design this solution.

3- The absence of the stirrups' bottom branch due to a possible corrosion did not compromise the shear behaviour of the rehabilitated beams.

4- The criterion to design a rehabilitated beam with the same load capacity or with the same deflection at service load as the reference RC beam with conventional steel reinforcement was satisfied. One of the proposed repaired solutions was able to keep both the deflection and the ultimate load capacity of the original beam.

5- The rehabilitated beams with GFRP bars exhibited a bilinear behaviour until failure in terms of load-deflection as expected since the ductile performance of the reference beam with steel reinforcement is not possible to replicate due to the GFRP material linear elastic property until failure.

6- The conic heads at the end of the GFRP bars inserted in the concrete holes filled with epoxy resin were sufficient to ensure their anchorage at the ends of the beams.

\section{Acknowledgements}

The authors wish to acknowledge Schoeck Company for the interest on this research and the support of $50 \%$ of the GFRP rebars used in this work. The support of Beto Madeira/Cimentos Madeira in providing all the needed concrete is gratefully appreciated. Finally, the support of the Madeira Island LREC laboratory in providing all the necessary equipment and manpower for the experimental campaign is also greatly acknowledged.

\section{References}

[1] Malumbela G, Alexander M, Moyo P. Variation of steel loss and its effect on the ultimate flexural capacity of RC beams corroded and repaired under load. Constr Build Mater 2010;24(6):1051-9.

[2] El-Nemr A, Ahmed EA, Brahim B. Flexural behavior and serviceability of normal- and high-strength concrete beams reinforced with glass fiberreinforced polymer bars. Struct J 2013;110(06).

[3] Zhu W et al. Effect of corrosion of reinforcement on the mechanical behaviour of highly corroded RC beams. Eng Struct 2013;56:544-54.

[4] Xie J-H, Hu R-L. Experimental study on rehabilitation of corrosion-damaged reinforced concrete beams with carbon fiber reinforced polymer. Constr Build Mater 2013;38:708-16.

[5] Al-Saidy AH et al. Structural performance of corroded RC beams repaired with CFRP sheets. Compos Struct 2010;92(8):1931-8.

[6] Badawi M, Soudki K. CFRP repair of RC beams with shear-span and full-span corrosions. J Compos Constr 2010;14(3):323-35.

[7] Quantrill RJ, Hollaway LC. The flexural rehabilitation of reinforced concrete beams by the use of prestressed advanced composite plates. Compos Sci Technol 1998;58(8):1259-75.

[8] Spadea G et al. Structural effectiveness of FRP materials in strengthening RC beams. Eng Struct 2015;99:631-41.

[9] França PMM. Reinforced concrete beams strengthened with prestressed CFRP laminates $\mathrm{PhD}$ thesis. Universidade Técnica de Lisboa -Instituto Superior Técnico; 2007.

[10] Firmo JP, Correia JR, França P. Fire behaviour of reinforced concrete beams strengthened with CFRP laminates: protection systems with insulation of the anchorage zones. Compos B Eng 2012;43(3):1545-56.

[11] Hashemi S, Al-Mahaidi R. Experimental and finite element analysis of flexura behavior of FRP-strengthened RC beams using cement-based adhesives. Constr Build Mater 2012;26(1):268-73.

[12] 440.1R-06 A. Guide for the design and construction of structural concrete reinforced with FRP Bars. Farmington Hills, USA: American Concrete Institute; 2006.

[13] CEB-FIP, FIB 40 - Bulletin n. 40 - FRP reinforcement in RC structures - design and use of fibre reinforced polymer reinforcement (FRP) in reinforced concrete structures. International Federation for Structural Concrete (FIB); 2007.

[14] Houssam AT, Mohamed S. Flexural behavior of concrete beams reinforced with glass fiber-reinforced polymer (GFRP) bars. Struct J 2000;97(5):712-9.

[15] Vijay PV, Hota VSG. Bending behavior and deformability of glass fiberreinforced polymer reinforced concrete members. Struct J 2001;98 (6):834-42. 
[16] Zhao W, Pilakoutas K, Waldron P. FRP reinforced concrete: calculations for deflections. In: Proceedings of the 3rd symposium on non-metallic (FRP) reinforcement for concrete structures (FRPRCS-3).

[17] 318-11 A. Building code requirements for structural concrete; 2011.

[18] Yost JR, Gross SP, Dinehart DW. Effective moment of inertia for glass fiberreinforced polymer-reinforced concrete beams. ACI Struct J 2003;100 (6):732-9.

[19] Toutanji HaDY. Deflection and crack-width prediction of concrete beams reinforced with glass FRP rods. J Constr Build Mater 2003;17:69-74.

[20] Pecce M, Manfredi G, Consenza E. Experimental response and code models of GFRP RC beams in bending. ASCE J Compos Constr 2000;4(4):182-90.

[21] Bischoff PHaSA. Effective moment of inertia for calculating concrete members containing steel reinforcement fiber-reinforced polymer reinforcement. AC Struct J 2007;104(1):68-76.

[22] Joseph Robert Yost SPG, David WD. Effective moment of inertia for glass fiberreinforced polymer-reinforced concrete beams. Struct J 2003;100(6).

[23] Kreit A et al. Repairing corroded RC beam with near-surface mounted CFRP rods. Mater Struct 2011;44(7):1205-17.

[24] Zhang H, He L, Li G. Bond failure performances between near-surface mounted FRP bars and concrete for flexural strengthening concrete structures, The Sixth International Conference on Engineering Failure Analysis. Eng Fail Anal 2015;56:39-50.

[25] IPQ EN 206-9:2010 concrete. Additional rules for self-compacting concrete (SCC). IPQ - Instituto Português da Qualidade: Portugal; 2010. p. 30.
[26] Nogichi T et al. A practical equation for elastic modulus of concrete. ACI Struct J 2009;106(5):7.

[27] 1992-1-1 NE. Eurocode 2: design of concrete structures - part 1-1: general rules and rules for building. European Committee for Standardization (CEN); 2010.

[28] IPQ NP EN ISO 6892: Materiais metálicos. Ensaio de Tração Parte 1: método de ensaio à temperatura ambiente; 2012.

[29] Schoeck. Schöck's website. Schoeck; 2014.

[30] Schoeck. Schoeck Combar; 2013.

[31] Gonçalves JFG. Aderência de Varões GFRP no betão. In: Centro de Ciências Exactas e da Engenharia. Funchal, Portugal: Universidade da Madeira; 2014. p. 135.

[32] Mapei. Adesilex PG1 - two component thixotropic epoxic adhesives for structural bonding. Lusomapei S.A.: Milan; 2013.

[33] TML. Strain gauge performance characteristics; 2014.

[34] Gangarao PVVHVS. Bending behavior and deformability of glass fiberreinforced polymer reinforced concrete members. ACI Struct J 2001;98 (6):834-42.

[35] Pilakoutas K, Neocleous K, Barnes B, O’Neil EF. Design philosophy issues of fibres reinforced polymer reinforced concrete structures. J Compos Constr 1997;6(3):154-61.

[36] EC2, C.-. NP EN 1992-1-1 - Eurocode 2: design of concrete structures - part 11: general rules and rules for building. In: European committee for standardization (CEN). European Committee for Standardization (CEN); 2010. 